\title{
Brain atrophy in multiple sclerosis: mechanisms, clinical relevance and treatment options
}

\author{
Athina Andravizou ${ }^{1 \dagger}$, Efthimios Dardiotis ${ }^{1+}{ }^{-0}$, Artemios Artemiadis ${ }^{2}$, Maria Sokratous $^{1,3}$, Vasileios Siokas $^{1}$, \\ Zisis Tsouris ${ }^{1}$, Athina-Maria Aloizou ${ }^{1}$, loannis Nikolaidis ${ }^{4}$, Christos Bakirtzis ${ }^{4}$, Georgios Tsivgoulis ${ }^{5}$, \\ Georgia Deretzi ${ }^{6}$, Nikolaos Grigoriadis ${ }^{4}$, Dimitrios P. Bogdanos ${ }^{3}$ and Georgios M. Hadjigeorgiou ${ }^{1,7^{*}}$
}

\begin{abstract}
Multiple sclerosis (MS) is an immune-mediated disease of the central nervous system characterized by focal or diffuse inflammation, demyelination, axonal loss and neurodegeneration. Brain atrophy can be seen in the earliest stages of MS, progresses faster compared to healthy adults, and is a reliable predictor of future physical and cognitive disability. In addition, it is widely accepted to be a valid, sensitive and reproducible measure of neurodegeneration in MS. Reducing the rate of brain atrophy has only recently been incorporated as a critical endpoint into the clinical trials of new or emerging disease modifying drugs (DMDs) in MS. With the advent of easily accessible neuroimaging softwares along with the accumulating evidence, clinicians may be able to use brain atrophy measures in their everyday clinical practice to monitor disease course and response to DMDs. In this review, we will describe the different mechanisms contributing to brain atrophy, their clinical relevance on disease presentation and course and the effect of current or emergent DMDs on brain atrophy and neuroprotection.
\end{abstract}

Keywords: Multiple sclerosis, Bran, Atrophy, Neurodegeneration, Axon, Inflammation, Neuroprotection, Drugs

\section{Introduction}

Multiple sclerosis (MS) is an immune-mediated disease that affects the entire central nervous system (CNS) [13]. Magnetic resonance imaging (MRI) lesions are wellscattered at white matter (WM) and grey matter (GM) [4], while normal-appearing brain tissue in MRI also seems to be affected in pathological studies [4]. Brain atrophy, the gradual loss of brain volume, is quite extensive in MS, nearly $0.5-1.35 \%$ per year, far off the limits of normal aging $[5,6]$. It arises early in the course of the disease, accelerates with disease progression [7-12] but is attenuated by disease-modifying drugs [13].

\footnotetext{
*Correspondence: gmhadji@med.uth.gr

${ }^{\dagger}$ Athina Andravizou and Efthimios Dardiotis shared first authorship

${ }^{1}$ Department of Neurology, Laboratory of Neurogenetics, Faculty of Medicine, University of Thessaly, University Hospital of Larissa, Biopolis, Mezourlo Hill, 41100 Larissa, Greece

Full list of author information is available at the end of the article
}

There has been increasing interest in measuring tissue loss in CNS, as it represents the net effect of all destructive pathogenic processes during the disease course [1417]. It is worth recalling that neurons occupy almost half $(46 \%)$ of the tissue volume, myelin is $24 \%$, and glial and other cells almost 30\% [5]. GM [4] holds much less myelin than WM (about one tenth), while neurons comprise its most abundant component [18]. Relative to glial cells, oligodendrocytes outweigh the number of astrocytes, microglia and oligodendrocyte progenitor cells, although the exact percentage is still unknown $[19,20]$.

Atrophy in MS is often considered to be the result of extensive axonal transection and demyelination [21-23]. The contribution of neuroglia may be less clear; reactive gliosis has the potential to mask considerable tissue loss in WM lesions [24, 25]. Measurement of brain atrophy is also considerably influenced by the amount of tissue fluids [26], which is increased by active inflammation and vasogenic edema in WM plaques, and decreased during 
treatment with agents with strong anti-inflammatory properties (pseudoatrophy effect) $[14,26]$.

Transient volume changes could also be attributed to idiosyncrasic and technical factors [14]. Dehydration may affect functional integrity of neuroglial cells, while decreased protein levels mainly affect synaptic densities [26]. Unlike demyelination, water volume fluctuations and transient biological factors, neuroaxonal damage is irreversible in CNS, and atrophy is primarily considered to reflect this neurodegenerative component in MS [2730]. Finally, the atrophy rates may also be influenced to some extent by the genetic makeup of a person; Human leukocyte antigen (HLA) genotypes considered as 'high risk for MS', namely DRB1 and DQB1, have been associated with significantly lower WM and GM volumes, alongside with higher mean annualized percentage of brain volume change (PBVC) compared with medium and low risk HLA genotypes independent from patients clinical features (age, gender, disease course) or the DMTs used [31].

\section{Pathogenesis of brain atrophy The time trajectory of brain atrophy}

Focal tissue loss in WM plaques is undoubtedly a major contributor to brain atrophy. However, the correlation between demyelination foci and whole brain atrophy is still a matter of debate [16]. Some studies have found a strong association [32, 33], while others have not [25, 34$36]$, suggesting that separate pathologic processes may also contribute to tissue destruction.

Chard et al. [37] in a longitudinal 14-year study found that atrophy is more related to early rather than late focal lesion volumes. Inflammation may be an important contributor to global tissue loss in early disease stages (i.e. in clinically isolated syndrome). As the disease progresses, additional mechanisms emerge that are, at least partly, independent from WM injury, such as microglia activation, meningeal inflammation, iron deposition, oxidative stress and diffuse axonal damage in normal appearing white matter (NAWM). The lack of a significant relationship between white matter fraction (WMF) and T2 lesion load [34, 38] further support this hypothesis. Biopsy studies also confirm that the atrophy may proceed even in the absence of inflammation $[39,40]$.

Regional atrophy studies may also be helpful. Indeed, the volume loss of deep GM structures may be present in the early stages of the disease and it is strongly correlated with the disease course [41]. In MS, brain atrophy may develop in different CNS structures and varies depending on the clinical disease phenotypes; ventricular enlargement is more prominent in relapsing-remitting MS [RRMS], whereas cortical atrophy seems to be more important in the progressive forms of the disease [42].
All things considered, it has been suggested that the pathogenic trajectory of brain atrophy changes with disease progression; from primarily inflammatory to less inflammatory and primarily neurodegenerative in the late stages of the disease $[43,44]$.

\section{Pathogenesis of acute demyelination and axonal injury}

In the initial stages of MS, many different components of the adaptive and the innate immunity induce demyelination and neuronal loss [43]. The activation of autoreactive $\mathrm{CD} 4+\mathrm{T}$ lymphocytes in the peripheral immune system is necessary for their migration across the bloodbrain-barrier (BBB) and into the CNS. After myelin destruction, $\mathrm{T}$ cells are in situ reactivated by antigens within myelin debris and their clonal expansion results in multifocal demyelinating plaques [45]. Peripheral B lymphocytes are involved in the antigen presentation and initial stimulation of CD4 T cells. Also, they are an essential source of pro- and anti-inflammatory cytokines (IL-6 among others) promoting every autoimmunity response (driven by Th1, Th2, Th 17 cells) driving MS. In addition, the presence of chemokines (CXCL13) and survival factors (BAFF and APRIL) in the CSF of patients with MS, promotes the formation of meningeal follicle like structures, in progressive phases but also in early RRMS [46]. $\mathrm{T}$ cells and $\mathrm{B}$ cells may, therefore, play an equally important role in the immunopathology of MS [47].

Axonal destruction is quite extensive (up to $60-80 \%$ ) in all active WM lesions $[9,12,48]$ and the extend of axonal loss is related to the number of immune cells within the plaques [49]. Activated immune cells ( $\mathrm{T}$ and B cells) and microglia/macrophages release a number of pro-inflammatory cytokines (e.g. TNFa, INFY), proteolyticenzymes (e.g. perforin, granzymes) and free radicals (e.g. nitric oxide, glutamate) that can directly damage axons [50]. Additionally, axons may die secondarily, due to the loss of pre- and post-synaptic signals (i.e. dying-back and Wallerian axonal degeneration) in regions far from the lesion site [43].

Active MS lesions are characterized by profound heterogeneity regarding their demyelination pattern [51], which is persistent over time [52]. The most commonly observed patterns are pattern II, which is a complementand antibody-mediated demyelination, and pattern III, in which the initial event in lesion formation is a brief yet exorbitant oligodendrocyte injury [53]. In other patients with RRMS, new lesions are associated with $\mathrm{T}$ cells, and activated microglia only. Pathologic heterogeneity across individuals in demyelination may imply different stimuli in the initial inflammation or different vulnerability to tissue loss across individuals [54].

In WM lesions, inflammation and brain edema, demyelination, axonal loss, gliosis, and remyelination, all 
happen simultaneously [35, 55]. Brain edema which increases brain volume might bias atrophy measurements, but it resolves in the first few weeks after lesion formation. Notably, CNS has the capacity to use a great number of compensatory mechanisms (i.e. remyelination, redistribution of sodium channels, expression of neurotrophic factors etc.) to re-establish lost functioning to demyelinated foci [48].

To conclude, tissue loss due to inflammation and demyelination maybe partly reversible in RRMS [56, 57], while tissue loss and axonal damage due to mechanisms other than inflammation is irreversible, and remains the major component of brain atrophy especially in the progressive disease stages.

\section{Mechanisms of late axonal loss (Fig. 1)}

While the destruction of CNS myelin is associated with clinical relapses, acute or late axonal loss is considered to be the main cause of permanent clinical disability in MS [49]. Axons are more vulnerable to acute injury by inflammatory mediators, due to their shape and structure, compared to cell bodies or dendrites [43], while thin axons $(<2.5 \mu \mathrm{m}$ in diameter) are mainly affected $[24,58]$. Neurofilament light chain (NfL) protein is only expressed in neurons. It is an essential component of the axonal cytoskeleton, and reflects the axonal integrity and the stability of neurons. Under conditions of acute axonal transection, NfL are released and can be found as a result, in the cerebrospinal fluid (CSF) and blood of patients with MS. Of note, ultra high versus low blood NfL levels have been associated with MRI related (increased number of gadolinium enhancing or T2 lesion load, whole brain atrophy) and clinical measures (number of relapses, disability worsening) of disease activity and evolution and may, therefore, have prognostic value for patients and clinicians [59].

Transected axons and ovoids are abundant in MS lesions $[9,27]$ but, abnormalities have also been reported in chronic inactive plaques, in normal appearing white matter (NAWM), and cortical areas, in which inflammation is less prominent [48, 57]. Therefore, additional mechanisms of axonal loss coexist with disease progression. It should be noted that these mechanisms have been postulated for both acute and late axonal loss (i.e. "late" signifying the absence of apparent inflammation):

\section{lon overload}

Several ion channels show compensatory changes a few weeks after demyelination [60] a process that eventually promotes energy deficiency, and neurodegeneration. Aberrant expression of sodium channels, acid sensing ion channels, increased expression of maladaptive isoforms (i.e. $\mathrm{Na}_{\mathrm{v}} 1.6$ channels) [61], paranodal (Caspr) and juxtparanodal $\left(\mathrm{K}_{\mathrm{v}} 1.2\right)$ protein alterations [62] have also been detected in WM lesions, in NAWM, and GM. Alternation in the expression of these ion channels lead to intra-axonal calcium accumulation, and subsequent axonal degeneration and atrophy, particularly in secondary progressive MS [49].

\section{Mitochondria dysfunction}

There has been increasing interest in the role of mitochondrial injury in MS demyelination and axonal destruction. In acute inflammatory lesions mitochondrial nicotinamide adenine dinucleotide-hydrogen (NADH) oxidase [63] and complex IV defects (COX I) have been described, in axons, oligodendrocytes, and astrocytes [58]. In chronic inactive plaques, ionic imbalance and high energy demands result to swollen and dysfunctional mitochondria [64, 65], a phenomenon in which is partially reversed in remyelinating axons [66]. There are also additional mtDNA deletions in GM structures of patients with SPMS [67]. Furthermore, the respiration deficient neurons were diffusely distributed in the subcortical WM resulting in axonal loss in the absence of demyelination or inflammation. In oligodendrocytes, mitochondrial damage results in cell death and demyelination. Progenitor cells are also impaired, regarding their capacity to differentiate and produce myelin [48]. Plus, genetic defects in mitochondrial genes potentiate MS lesions [68]. From what can be deducted, mitochondrial dysfunction, in neurons and glia, is recognized as an important cause of atrophy and degeneration in MS and in other primarily neurodegenerative deceases such as Alzheimer's disease and Parkinson's disease [65, 69].

\section{Iron dysregulation}

Iron [Fe] loading accumulates with age and in patients with MS, it can further increase oxidative tissue loss. In the CNS, iron is mainly stored in oligodendrocytes, binding with ferritin. Under conditions of oxidative stress, such as MS lesions, when oligodendrocytes are destroyed, free iron $\left[\mathrm{Fe}^{2+}\right]$ is released in the extracellular space and becomes an additional source of reactive oxygen species (Fenton reaction: $\mathrm{Fe}^{2+}+\mathrm{H}_{2} \mathrm{O}_{2}=\mathrm{Fe}^{3+}+\mathrm{OH} .+\mathrm{OH}-$ ) [48]. Further, iron is released by activated glial cells, which become dystrophic and disintegrate, leading to a second wave of $\mathrm{Fe}^{2+}$ release.

Diffuse T2hypointenselesions, which represent increased iron deposition [70] are commonly found in patients with MS in cortical and deep GM areas (i.e. thalamus, basal ganglia, dentate nucleus [71-73] and WM plaques [74]. Notably, T2 hypointensity has been associated with brain atrophy and early axonal loss [73]. Furthermore, in progressive MS, there is a significant decrease in iron levels in NAWM [75]. Iron is important 


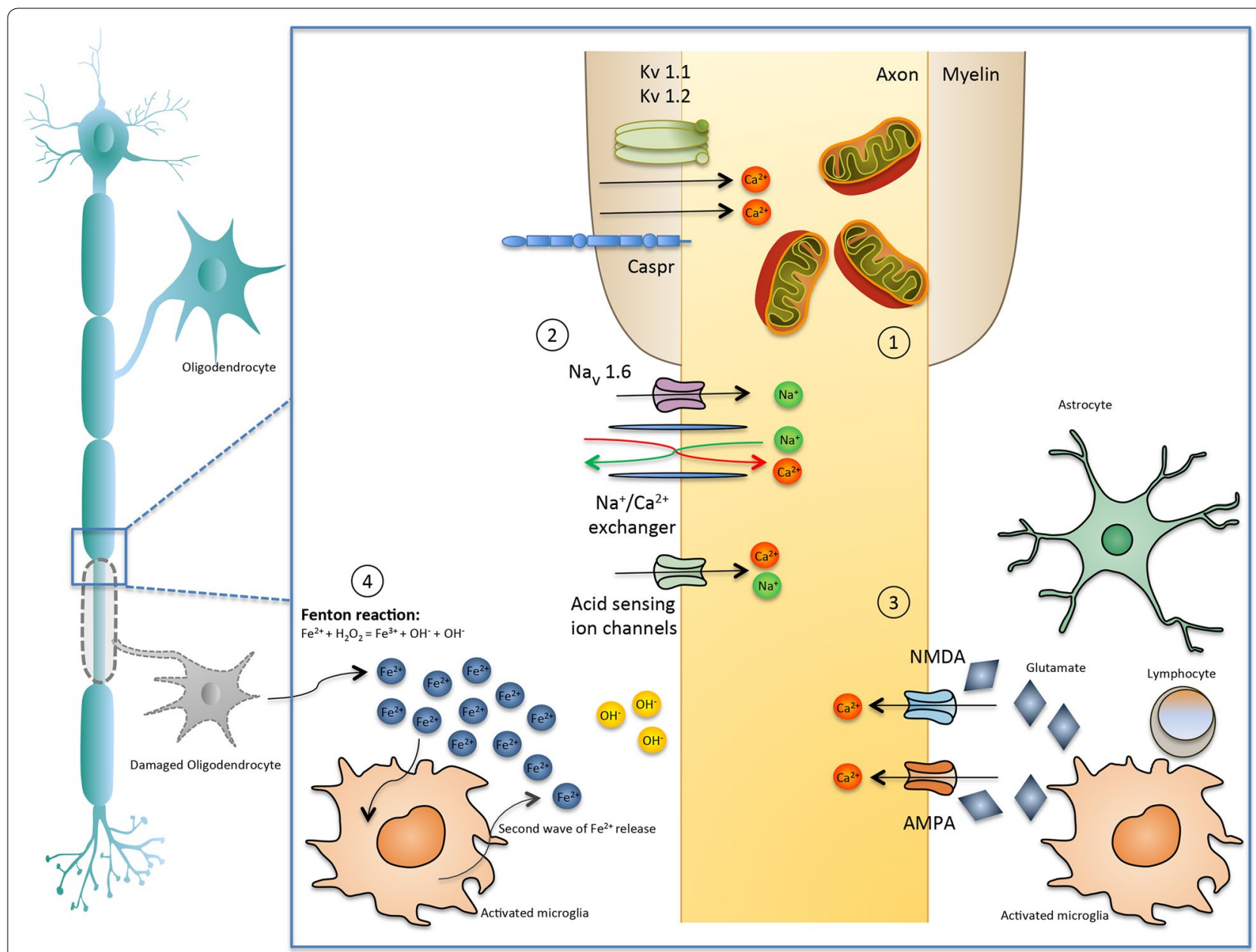

Fig. 1 Mechanisms of late axonal loss. Molecular and cellular mechanisms driving neurodegeneration and atrophy. Key elements are considered to be: (1) Mitochondria Dysfunction: Inflammation in acute demyelinating lesions lead to respiratory protein complexes inhibition, mitochondrial injury and dysfunction, release of apoptosis-inducing factors and mitochondrial DNA deletions. In chronic inactive plaques, ionic imbalance, high energy demands and clonal expansion of defective mitochondria further impair oxidative damage. These mitochondrial alterations of functional impairment and structural damage lead to histotoxic hypoxia and energy failure and consequently to neurodegeneration. [146] Upregulation of sodium channels, acid sensing ion channels and expression of maladaptive isoforms (Nav1.6 channels), paranodal (Caspr) and juxtparanodal (Kv1.2) protein lead to high energy demands, intra-axonal calcium accumulation, and subsequent axonal degeneration. (3) Glutamate Excitotoxicity: Increased glutamate production by activated microglial cells and lymphocytes, and impaired clearance by resident cells such as astrocytes lead to higher lever of glutamate. High levels of glutamate lead to over-activation of N-methyl-D-aspartate (NMDA) and a-amino-3-hydroxy-5-methyl-4-iso xazolepropionic acid (AMPA) receptors (which are permeable for calcium and sodium ions) and subsequent calcium overload and oligodendocyte and neuron cell death. (4) Iron release: In MS lesions free iron [Fe2+] is released in the extracellular space leading to production of highly reactive hydroxyl molecules $\left(\mathrm{OH}^{-}\right)$by the Fenton reaction. Further, iron is released by activated glial cells, which become dystrophic and disintegrate, leading to a second wave of $\mathrm{Fe}^{2+}$ release

for myelin synthesis and neurogenesis, and iron depletion in normal appearing tissue, may further promote diffuse axonal loss and CNS atrophy.

\section{Glutamate excitotoxicity}

Several lines of evidence suggest that glutamate could also mediate injury to myelin, oligodendrocytes and neurons in the autoimmune experimental encephalomyelitis (EAE) model and in MS [76]. Glutamate levels are elevated in CSF [77], in the centre of active plaques, on the borders of chronic active lesions [78], and in NAWM [79].

There are two factors intertwining for glutamate accumulation: increased glutamate production by activated microglial cells and lymphocytes, and impaired clearance by resident cells such as astrocytes. High levels of glutamate lead to the overactivation of $N$-methyl-D-aspartate (NMDA) and 
$\alpha$-amino-3-hydroxy-5-methyl-4-isoxazolepropionic acid (AMPA) [80] receptors (permeable for calcium and sodium ions) and subsequent calcium overload and oligodendocyte and neuron cell death.

\section{Clinical correlates of brain atrophy}

Clinical symptoms and signs do not usually correlate with changes seen on conventional MRI measures (the "clinical-MRI paradox") [81, 82]. Whole brain atrophy, on the other hand, has a significant imaging association with physical disability as measured by Expanded Disability Status Scale (EDSS) score [83-88]. In a longitudinal study, whole brain (WB) and cortical atrophy as well as other MRI related metrics such as the enlargement of ventricular CSF spaces have been associated with disability progression over a 10 year follow up [89]. Furthermore, brain volume changes during the first year after disease onset, estimated by PBVC, were the best predictor of future neurologic impairment [90] regardless of the intermediate relapse rate [91]. Increased brain volume loss (BVL) has been correlated disability progression, independent from the number of previous relapses or the T2 lesion load in RRMS [92].

In a similar vein, when patients with clinically definite MS were compared to patients with clinically isolated syndrome (CIS), at baseline, all brain volume metrics, except for cortical GM, were significantly lower in the MS cohort. Over a mean follow-up period of about 3 years, the annual PBVC values were significantly lower in CIS patients when compared to the MS cohort [93]. Neuropsychological impairment, affecting mental speed processing, episodic memory, executive functions and attention, may be present in up to $50 \%$ of patients with MS [94] and has been found to occur early in the disease course [95]. Changes of brain parenchymal fraction (BPF) have been shown to predict cognitive impairment over 2 years in patients with early MS [96]. Cortical atrophy was the best predictor of poor cognitive functioning, even when mild impairment was detected. Poorcognitive functioning has been associated with significant cortical thinning [97], especially in the fronto-parietal cortical and subcortical regions [98]. Pravatà et al. [98] specifically reported that the thinning of the right precuneus and high T2 lesion load were the best predictors of cognitive impairment. Strong correlations have also been reported between cognitive impairment and thalamic atrophy $[80,98,99]$. Not surprisingly, patients with brain atrophy and higher education or high "cognitive reserve" are relatively protected against cognitive decline [100].

Other clinical aspects of CNS atrophy include mood and personality disorders (i.e. euphoria, disinhibition, aggression, major depressive disorder) [101] autonomic dysfunction and sexual disorders [85]. Fatigue has been reported to be associated with GM atrophy in frontal regions [102] and depressed patients were found to present selective cortical thinning in the fronto-temporal regions, while the frontal thinning was found to be the best predictor for depression in MS patients [98].

Taken together, this growing body of evidence suggests that brain atrophy is a valid and sensitive measure of disease burden and progression in MS patients and may effectively be used in routine clinical practice and treatment trials.

\section{Effect of disease modifying treatments (Tables 1, 2 and 3)}

\section{Approved DMTs and brain volume outcomes}

The need of agents to control the inflammatory process in multiple sclerosis pathology is obvious, but the need for medications to halt brain atrophy progression and neurodegeneration is also evident. Currently approved treatments for MS differ in their effects on brain atrophy [103] (Table 1 for the first line therapies, Table 2 for the second line therapies and Table 3 for the emerging therapies).

In general, studies of traditional injectable treatments have not exerted robust beneficial effects in the rate of brain atrophy. Intramuscular IFN- $\beta-1$ a produced lower rates of brain volume loss (BVL) when compared to placebo during the second year of treatment in relapsingremitting MS patients $(-0.23 \%$ vs $-0.51 \% ; \mathrm{p}=0.03)$ [83, 104]. However, the subcutaneous (sc) IFN- $\beta$-1a produced inconsistent results in both CIS and RRMS patients [105-108]. BV data for intramuscular INF- $\beta-1 \mathrm{a}$ in CIS patients and for subcutaneous INF- $\beta-1 \mathrm{~b}$ in relapsing MS patients has not been made available to date. The addition of monthly oral methylprednisolone pulses to subcutaneous interferon beta-1a treatment provided no further gain in normalized BV change in two published trials against placebo [109, 110]. The approved long-acting pegylated interferon beta-1a has only shown limited and inconclusive evidence for a beneficial effect on BV change in RRMS [111, 112]. A possible delayed effect in reducing brain atrophy has been reported for Glatiramer acetate [GA] [113-119]. In the PReCISe clinical trial, GA failed to show an immediate effect on brain volume outcomes versus placebo $(-0.38 \%$ vs $0.33 \%)$, but the subsequent open label phase of the trial showed a clear-cut benefit on PBCV for the early treatment group, when compared to patients with delayed treatment onset (40\% reduction, $\mathrm{p}=0.0209)[114,115]$. In relapsing-remitting MS, data from the extension phase of the European/Canadian GA trial come back as negative [118].

Available oral therapies (Fingolimod, Teriflunomide, Dimethyl fumarate) have shown various effects on BV decline. Fingolimod has been reported consistentin 


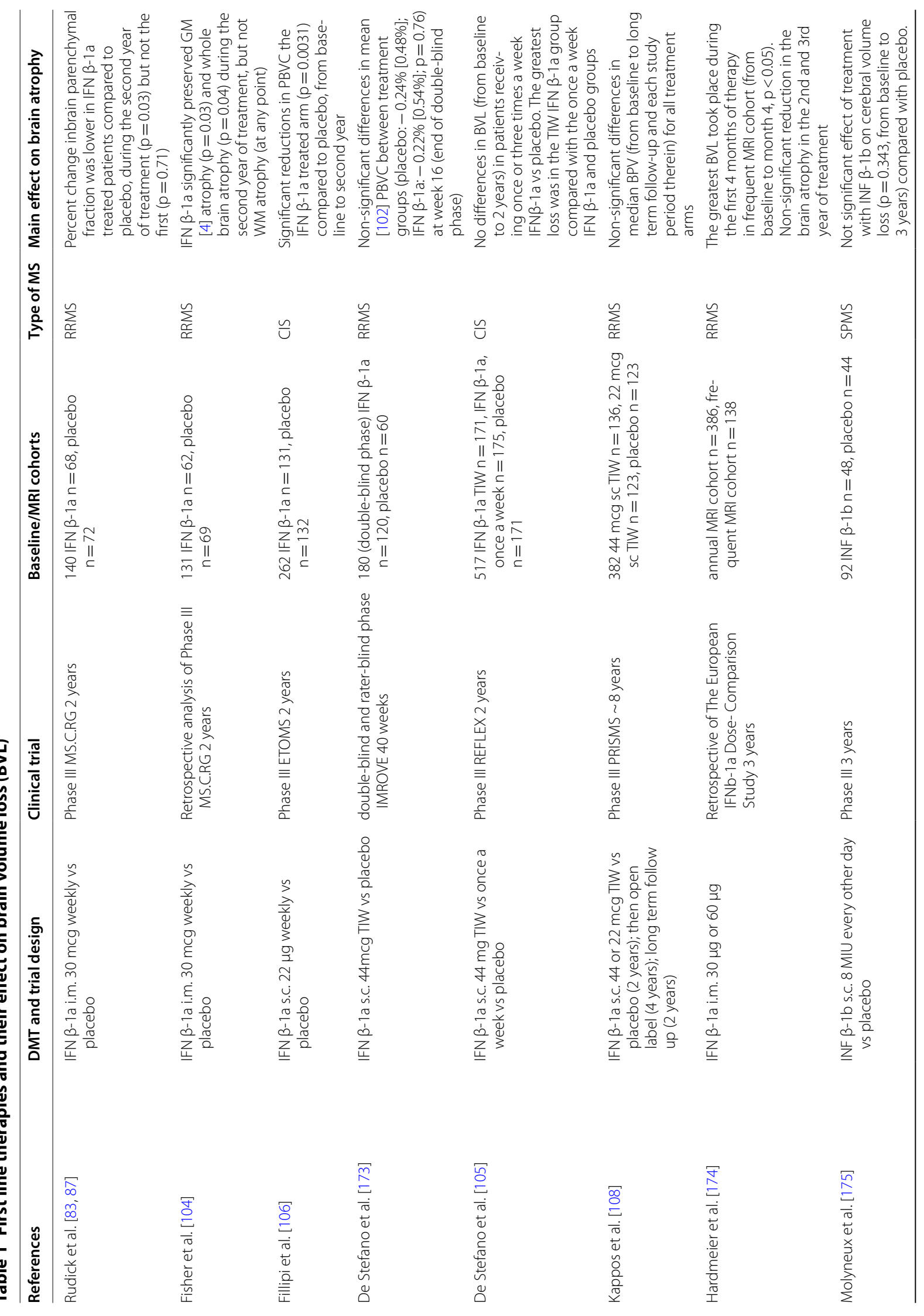




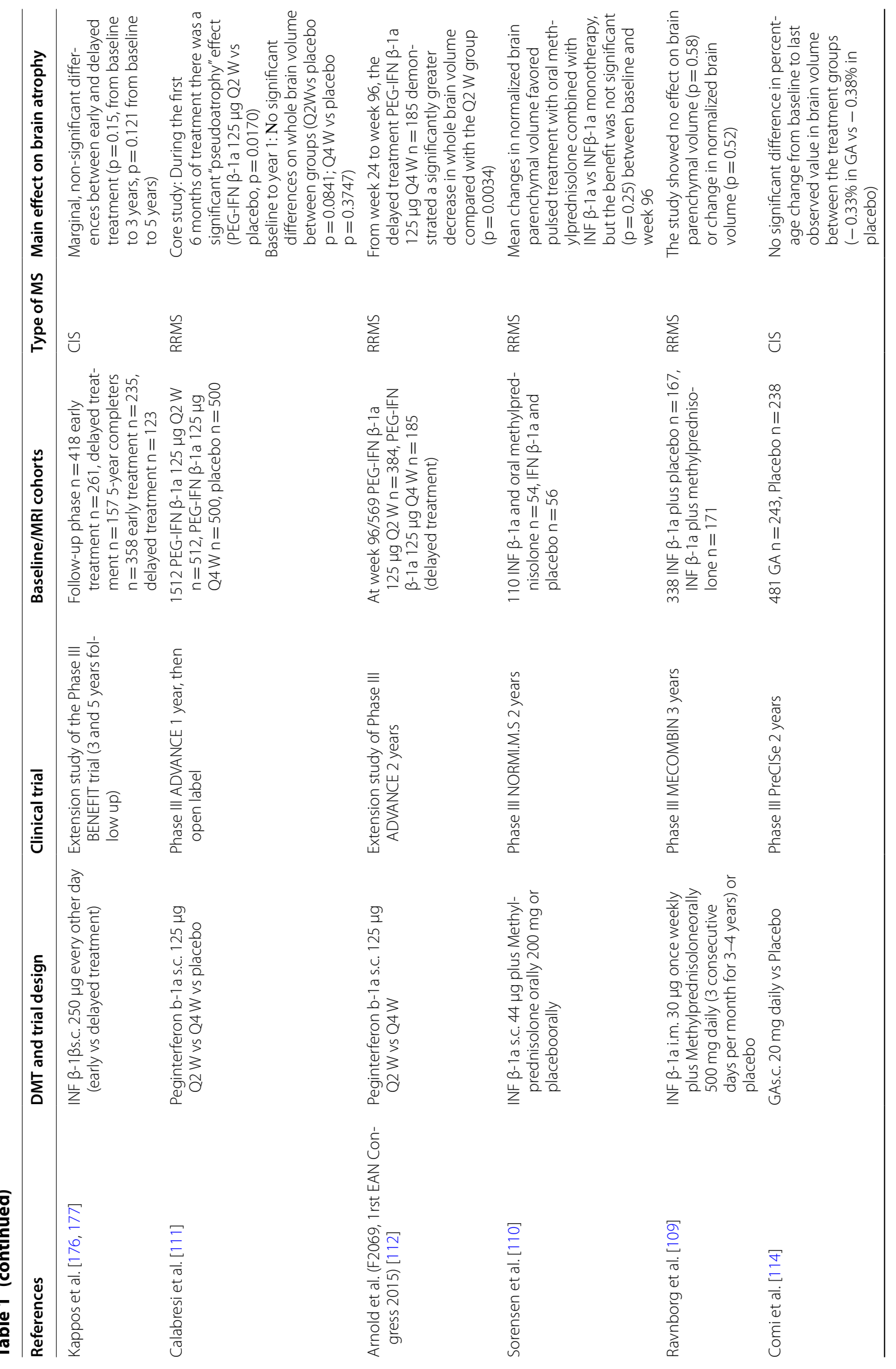




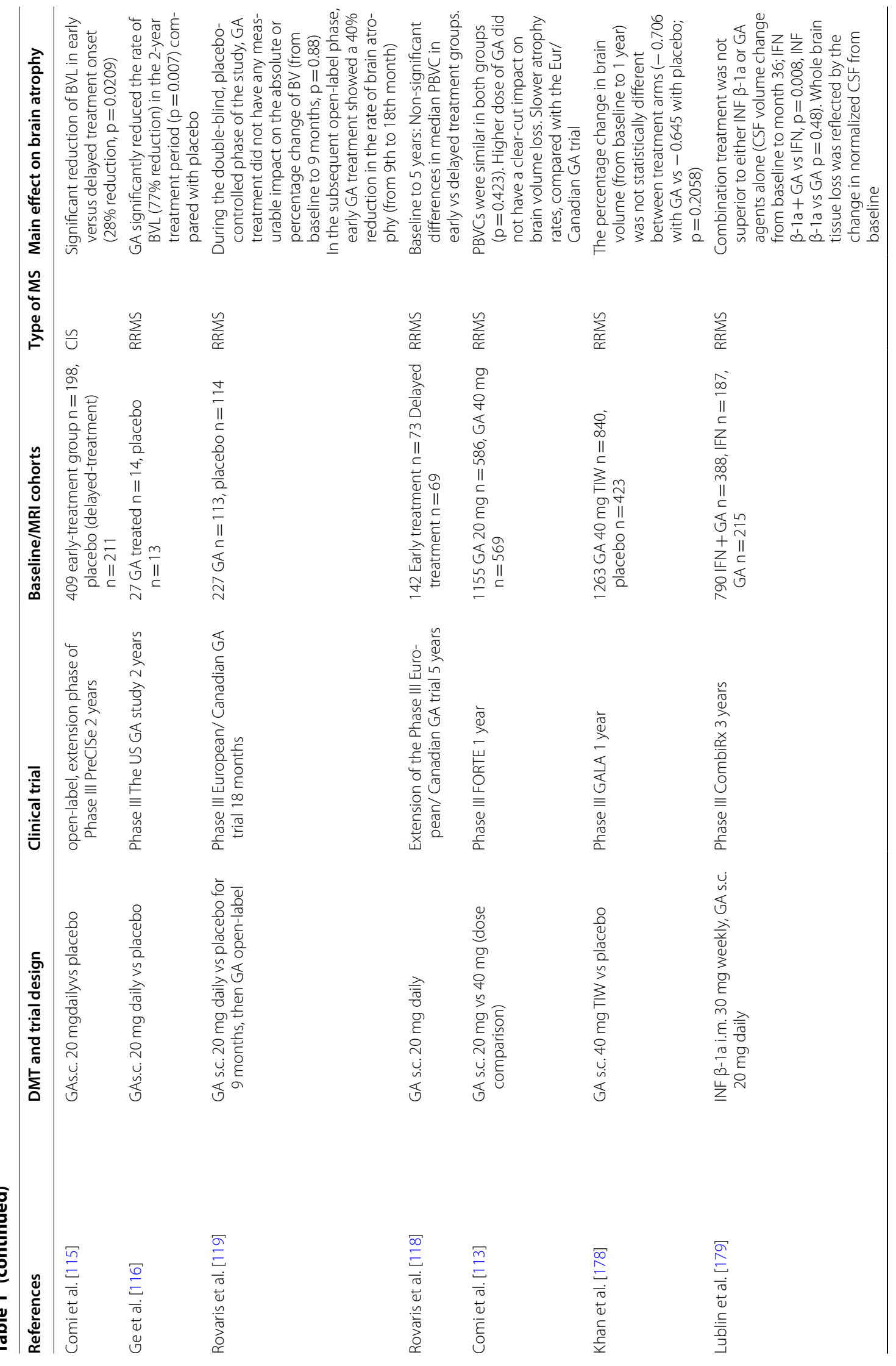




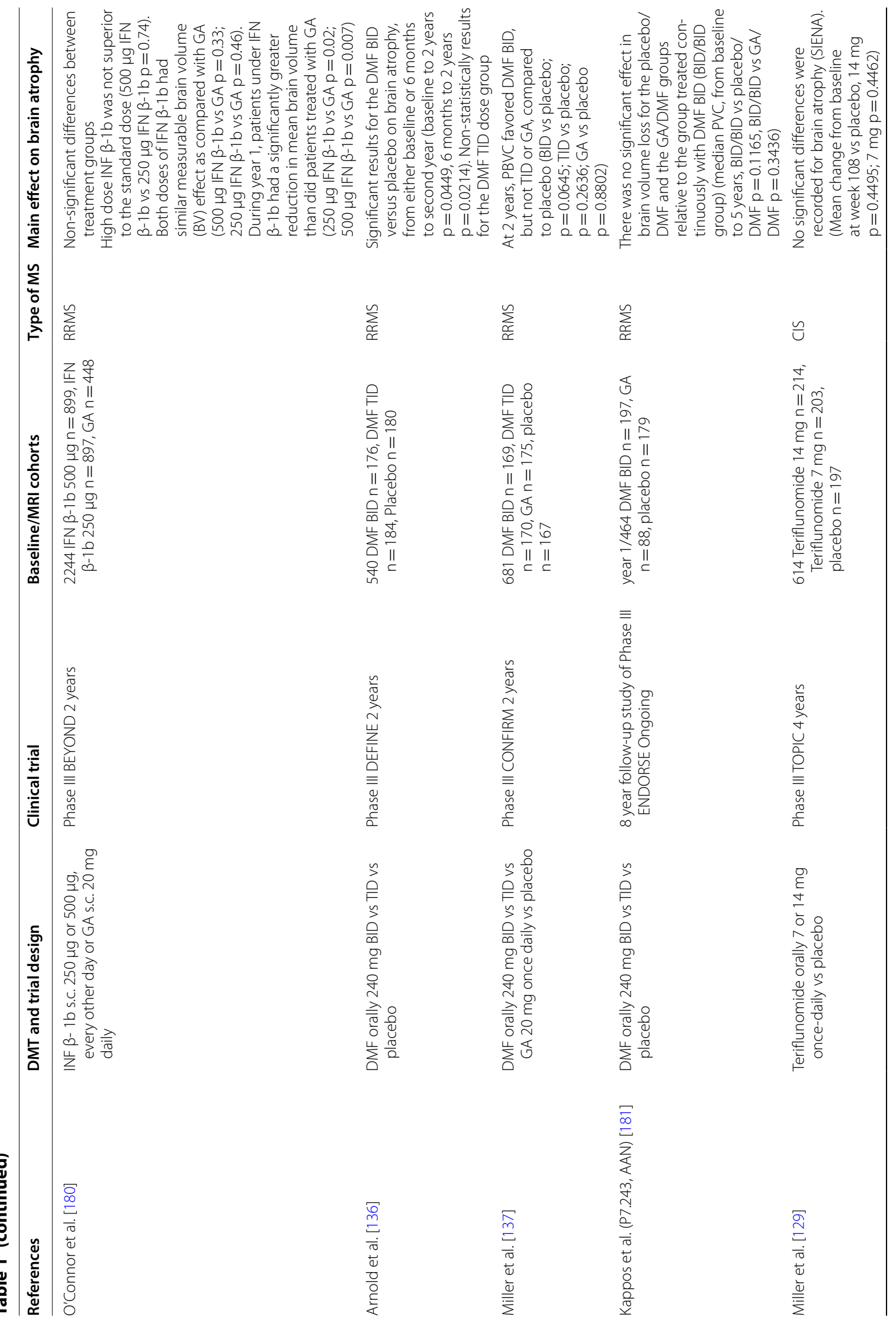




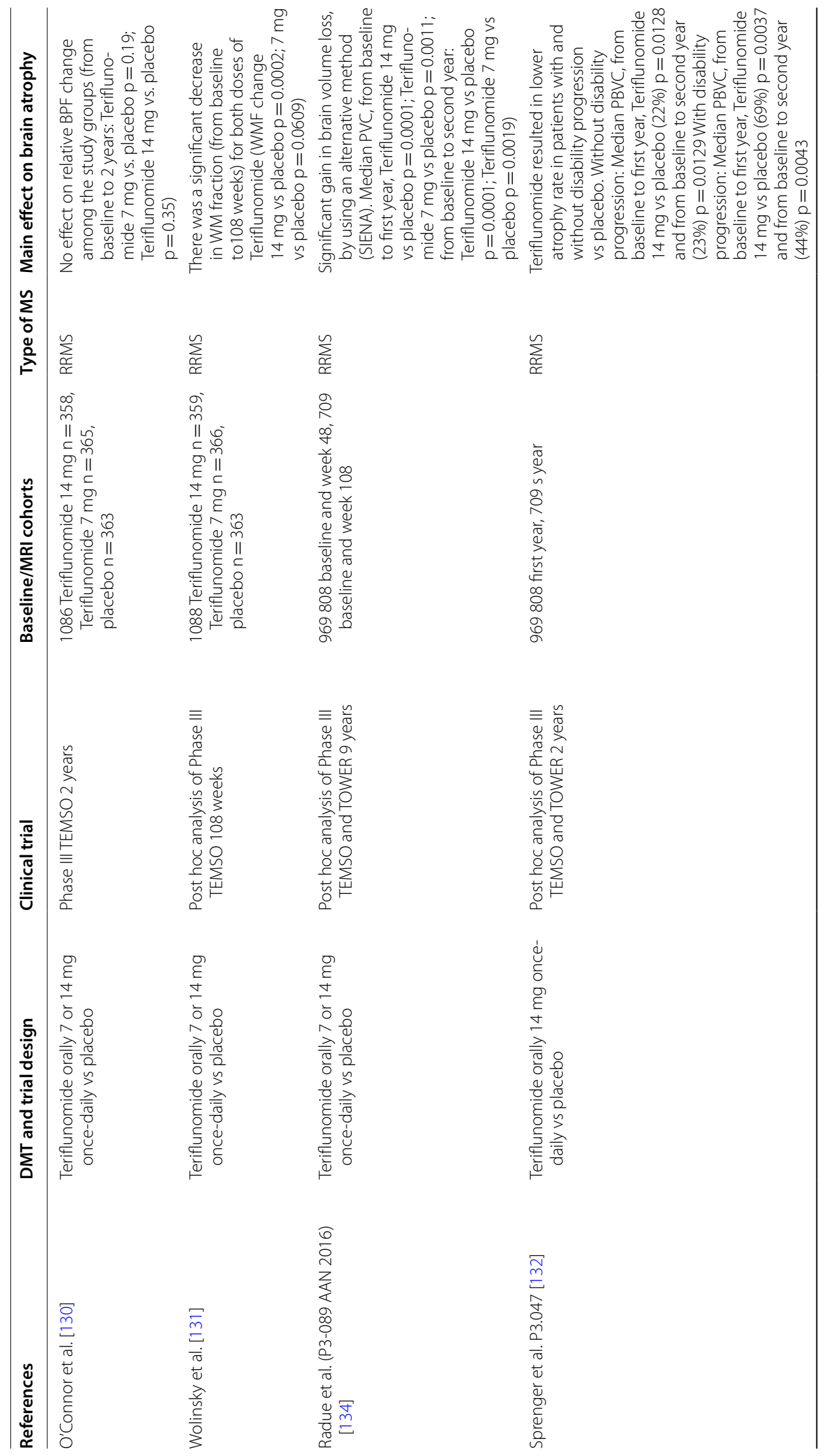




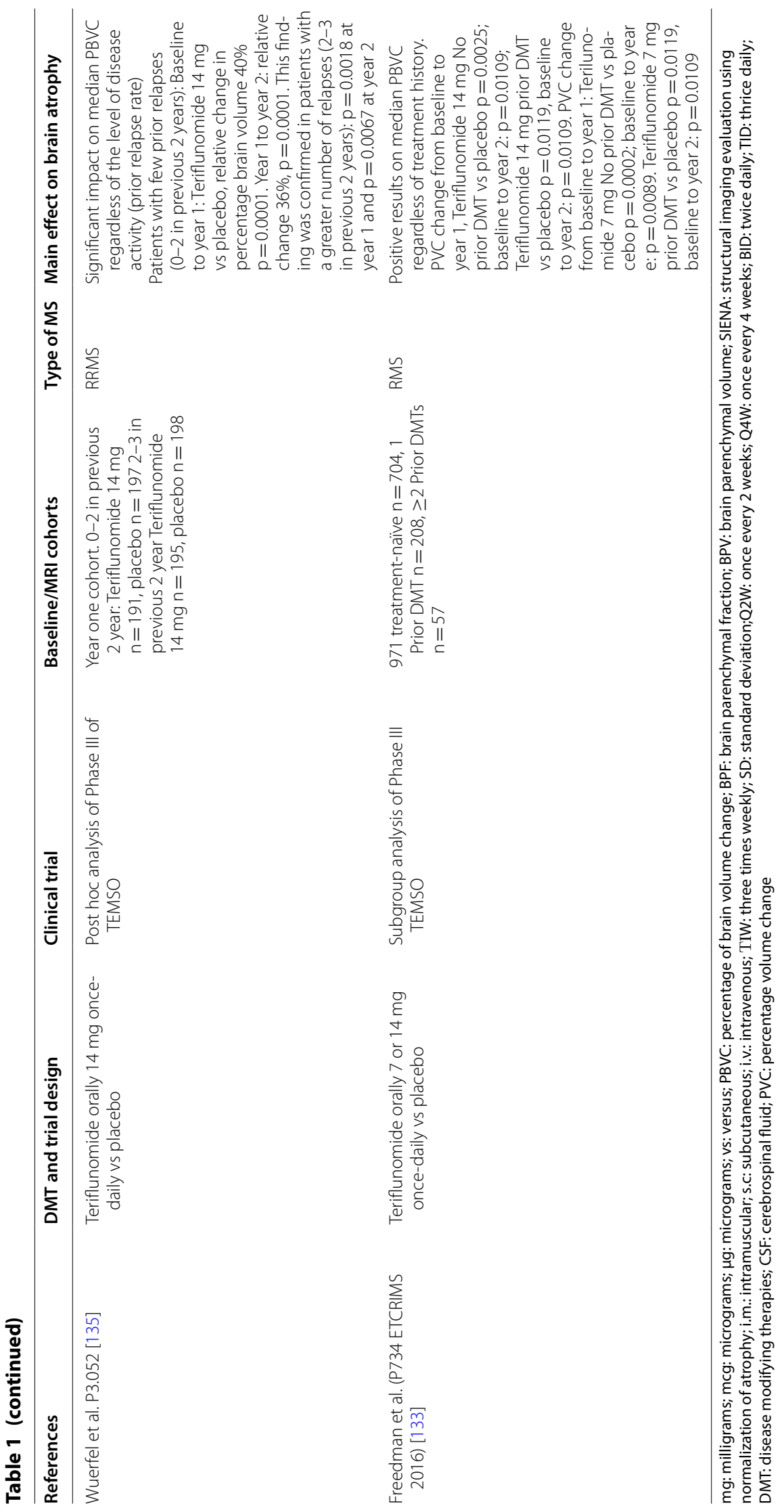




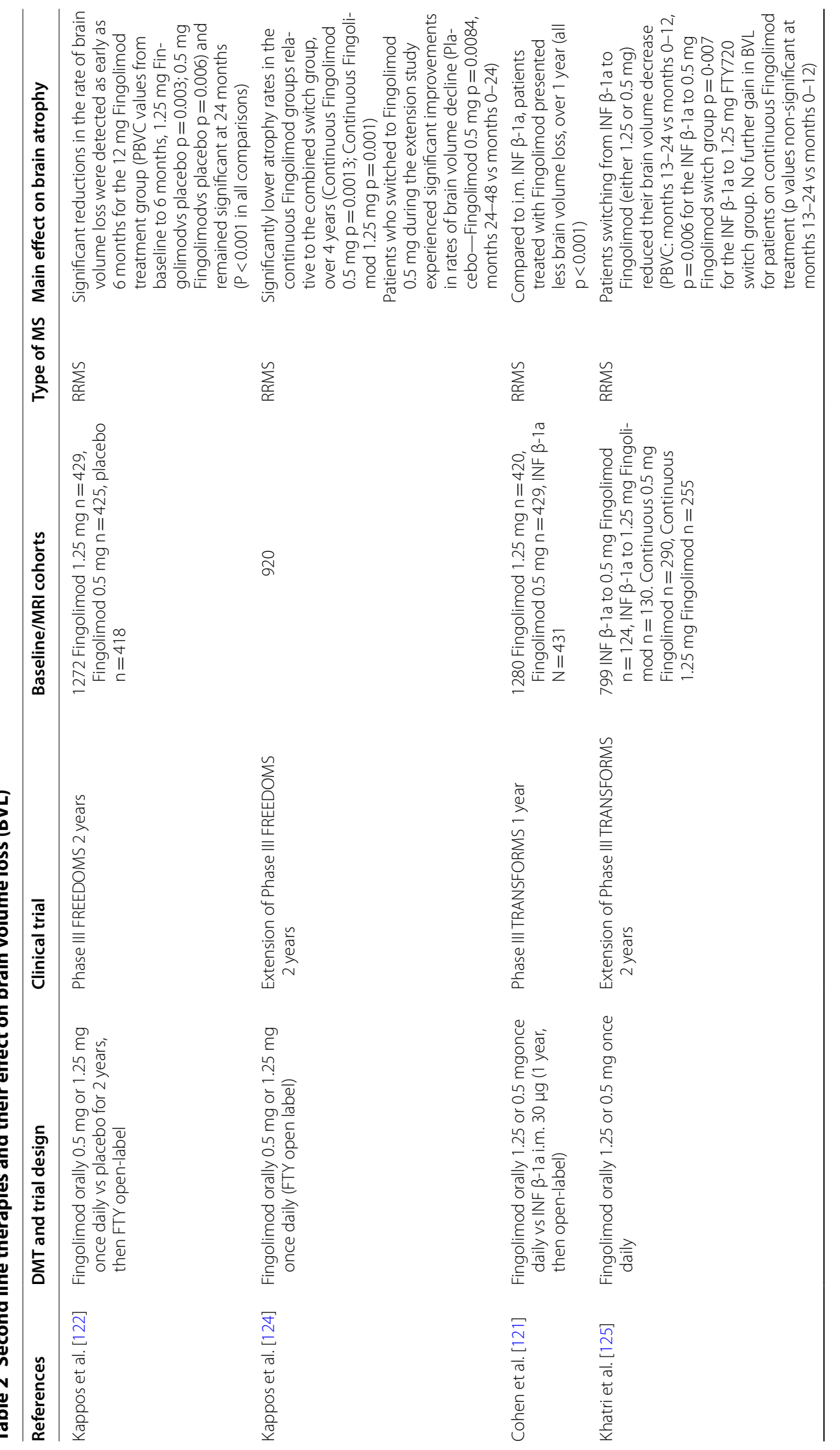




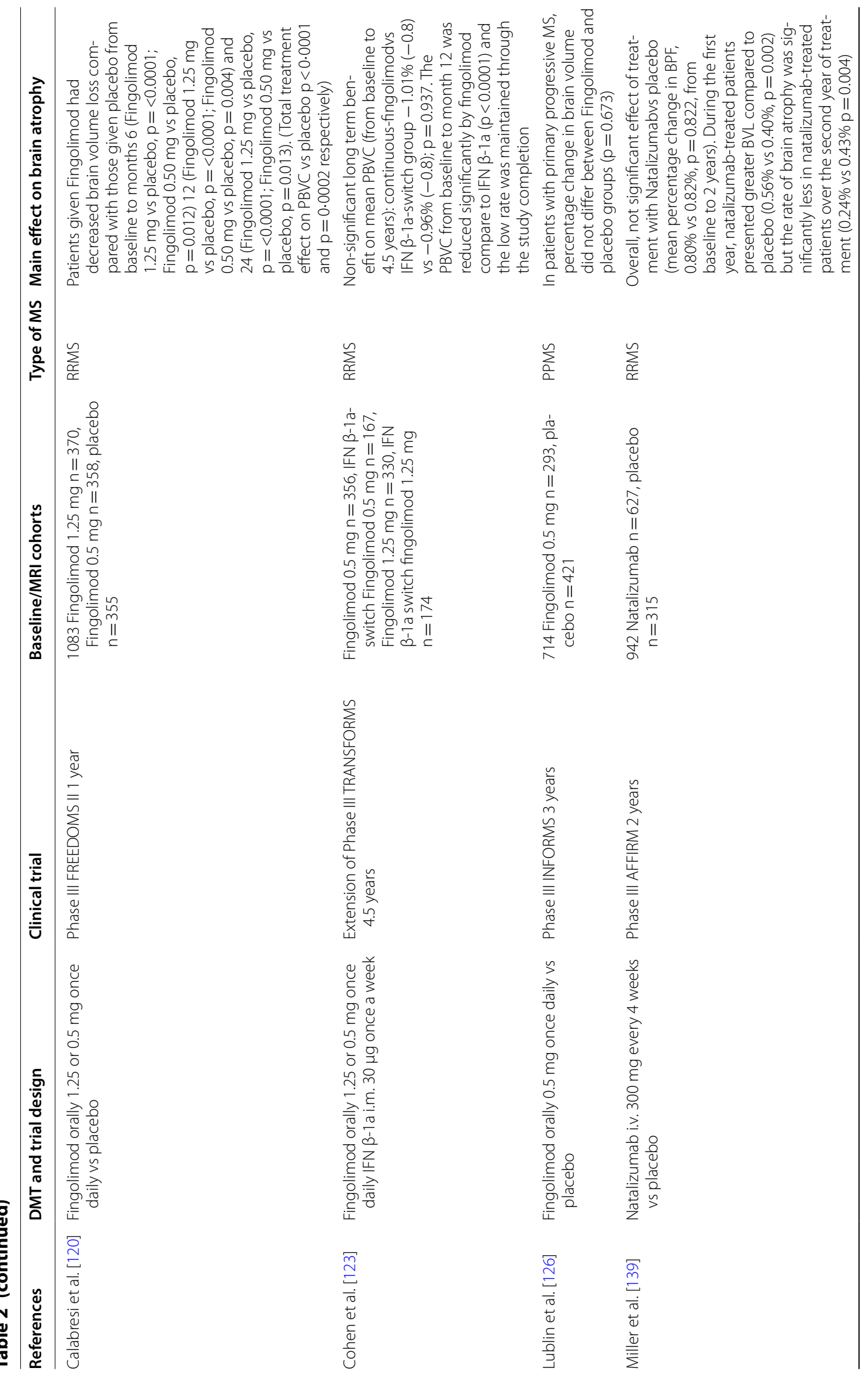




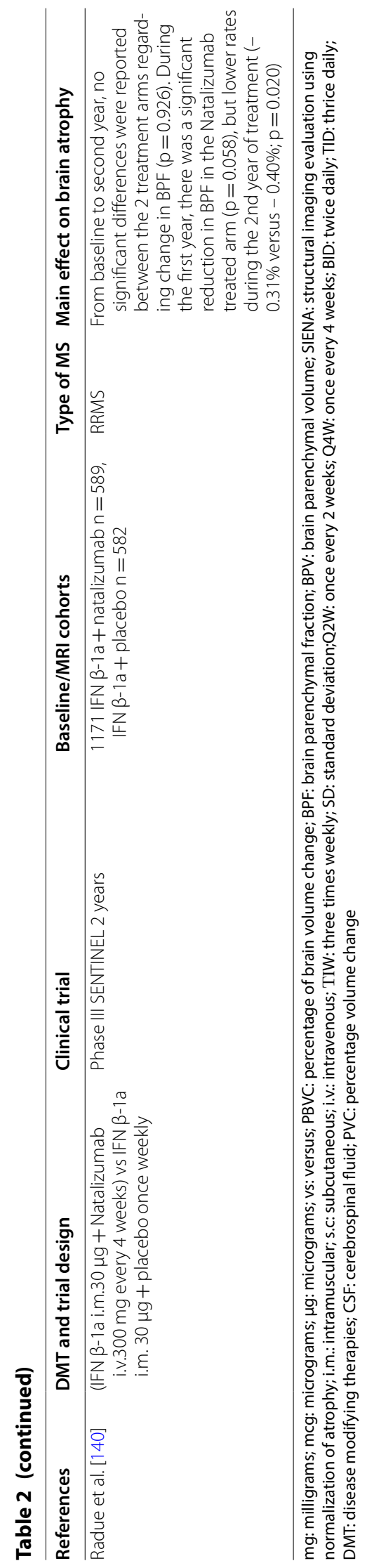




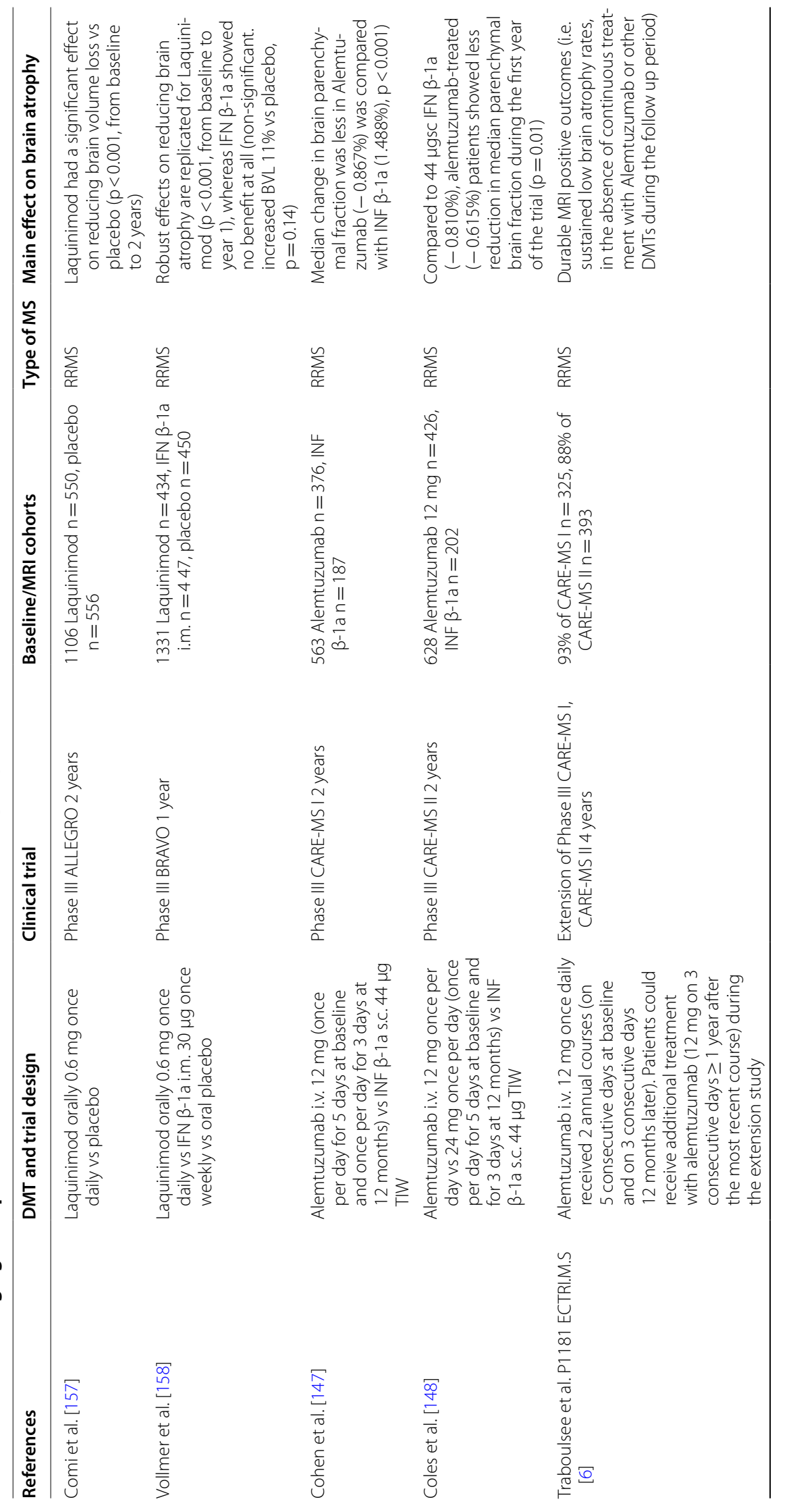




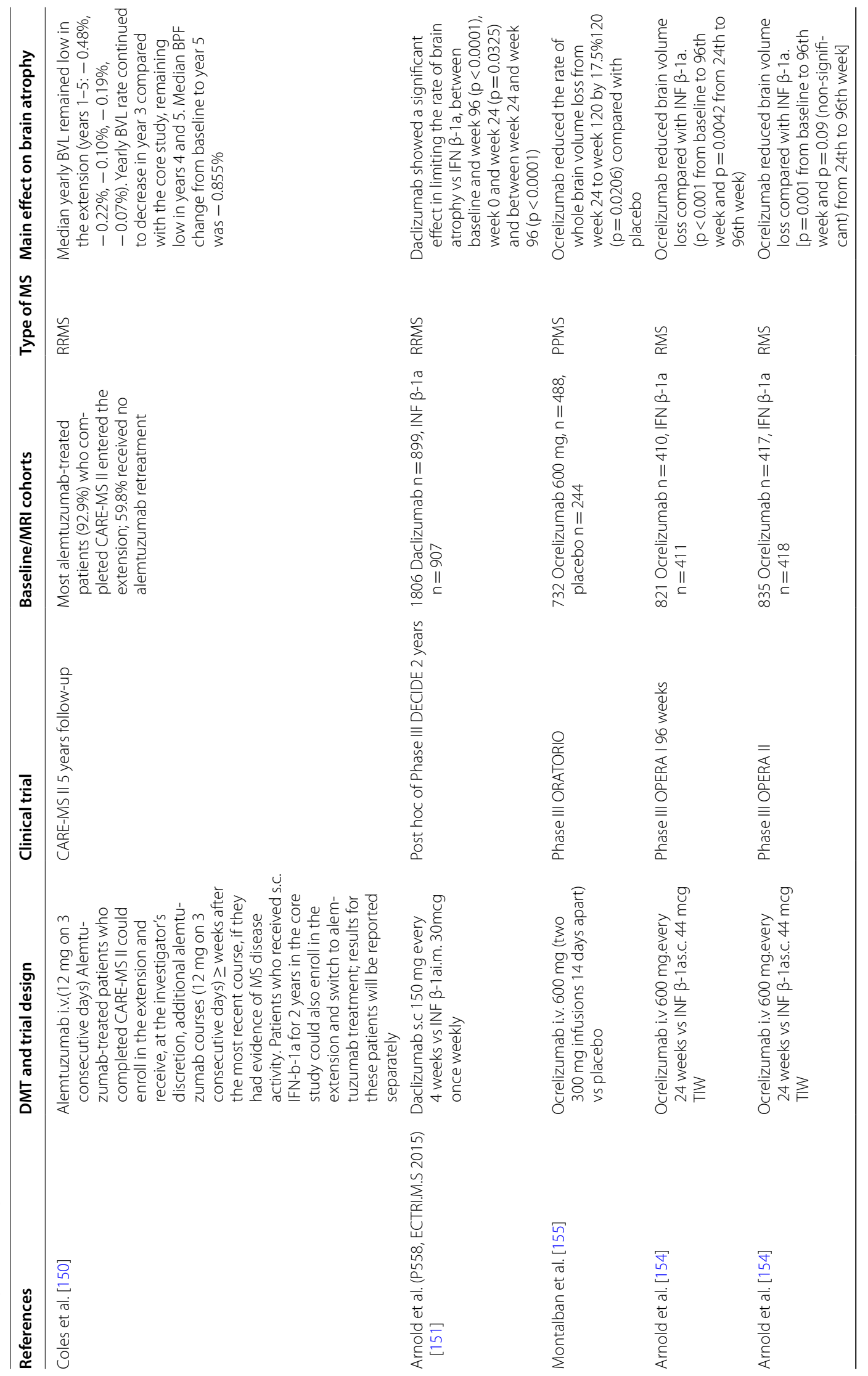




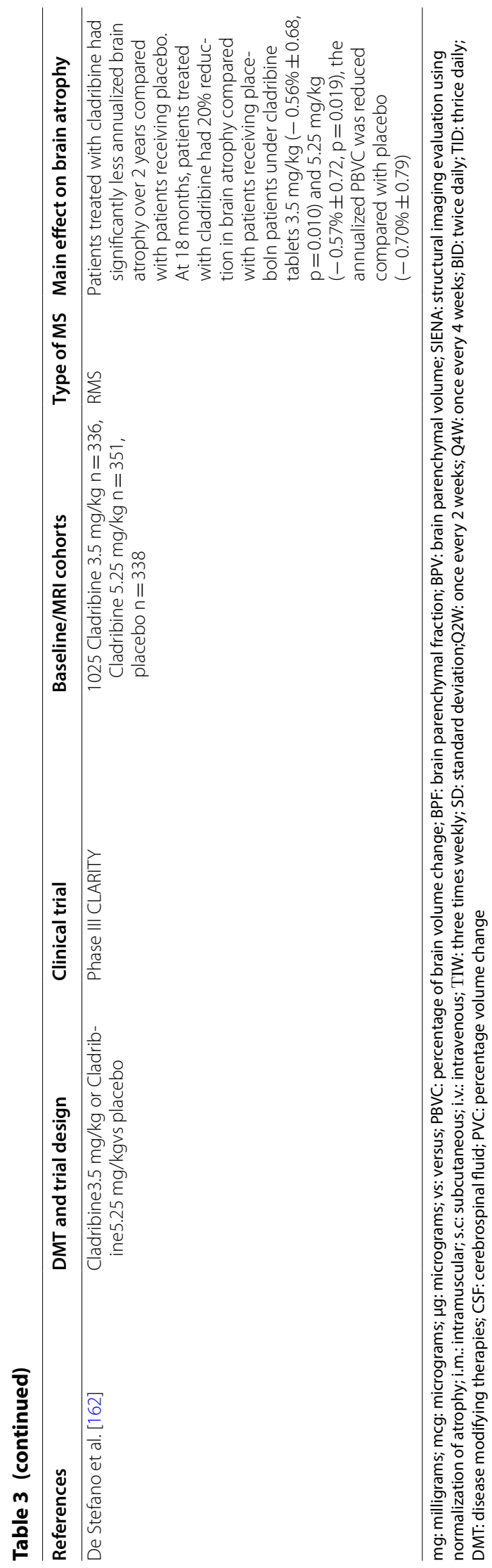


reducing median PBVC by approximately 30 to $45 \%$ versus placebo or IFN $\beta-1 \mathrm{a}$, in its three phase III clinical trials [120-122] and their extensions [123-125]. Of note, this reduction was observed as early as 6 months after treatment onset $[120,122]$. In the extension phase of the TRANFORMS trial, patients switching from intramuscular (i.m.) INF $\beta 1$ a to FTY720 slowed their median PBVC, and patients continuing on FTY720 sustained low atrophy rates, over the following 4.5 years of therapy [123]. However, no similar effects were reproduced in patients with the primary progressive form of MS, a finding that that could have otherwise strengthened the evidence for a direct action of fingolimod on brain cellular components [126]. Finally, further condoning the aforementioned observations, in a study by Yousuf et al. [127], cortical GM, alongside T2 lesion volume, remained stable in the cohort treated with fingolimod, as compared to the untreated group, where it decreased and increased respectively, in the first 2 years of treatment.

Regarding Teriflunomide [128], brain volume outcomes have been reported for clinically isolated syndrome and relapsing- remitting MS in the TOPIC and TEMSO clinical trials respectively. Both doses of $7 \mathrm{mg}$ or $14 \mathrm{mg}$ failed to show a clear effect on slowing BVL when compared to placebo $[129,130]$. However, when tissue specific volume changes were examined a significant reduction in the rate of WM loss was detected for the $14 \mathrm{mg}$ teriflunomide treatment arm versus placebo [131]. Similar results have recently been reported in 4 retrospective analyses of TOWER and TEMSO trials when an alternative method of brain loss evaluation was implemented [132-135].

Dimethyl fumarate (DMF/BG12) showed a $21 \%$ reduction in BVL compared to placebo in the DEFINE study (the $240 \mathrm{mg}$ twice daily regimen only) [136] and produced only marginal but beneficial effects in BVL reduction in the CONFIRM study [137]. A recent pilot study of 20 patients with RRMS showed a protective effect of DMF treatment in whole brain atrophy (PBVC: $-0.37 \pm 0.49 \%$ vs. $-1.04 \pm 0.67 \%, \mathrm{p}=0.005)$ and putamen atrophy $(-0.06 \pm 0.22$ vs. $-0.32 \pm 0.28 \mathrm{ml}, \mathrm{p}=0.02)$, but no effect on other subcortical volumes or total GM atrophy [138].

Natalizumab, a monoclonal antibody against the cell adhesion molecule a 4-integrin, in two pivotal clinical trials was found to increase the rate of BVL in the first year of treatment and then significantly reduced it when compared to the placebo in the second year $[139,140]$. Post-marketing observational studies confirmed that most of the BVL occurring while on Natalizumabtherapy takes place during the first months of therapy, and that it primarily involves WM volume changes [141, 142]. One trial has shown superiority of Natalizumab over conventional MS therapies (IFN- $\beta$ and GA) and placebo regarding cortical atrophy [143]. Recently, treatment with Natalizumabdid not affect the loss of brain volume compared to placebo in secondary progressive MS patients (ASCENT) [144]. The study by Arpín et al. [145] also suggests a neuroprotective effect of Natalizumab, after the measurement and comparison of the corpus calosum index, and the absence of brain atrophy in several patients under treatment during the follow up.

Alemtuzumab, a monoclonal antibody against cells that express the CD52, has demonstrated greater MRI and clinical improvement in comparison to IFNb-1a in its three pivotal studies in active relapsing MS patients [146-148]. Additionally, most patients remained free of disability and MRI progression, for the following 6 years of the initial treatment [6]. Brain atrophy measures showed that brain parenchymal fraction was smaller in Alemtuzumab compared to the INF $\beta$-1a treatment arm either in treatment naïve patients [149] or in participants who had relapsed on prior therapy [147-149]. Extension studies showed sustained low brain atrophy rates, in the absence of continuous treatment with Alemtuzumab or other DMTs during the follow up period [149]. The CARE-MS II 5-year follow-up study (2017) provided class III evidence that Alemtuzumab slows brain atrophy; the annual BVL rate continued to drop during the third year and remained low through the fourth and fifth year as well [150].

The immune-modulatory agent Daclizumab in a 3-year post hoc analysis of 899 RRMS patients was compared to IFN beta-1a on brain volume change. Median annualised PBVC was significantly reduced in the DAC treatment group during both the first and the second year of treatment (baseline-24th weeks: -0.674 vs -0.745 ; 24th-96th weeks: -0.511 vs -0.549 ; all $\mathrm{p}<0.0001$ ) in comparison to INF $\beta$ treatment [151], a finding which was consistent with previous longitudinal data [151-153].

Ocrelizumab is a humanized mAb designed to target CD20+B cells. MRI outcomes hint towards a positive effect on BVL and clinical disability progression. Treatment with Ocrelizumab has significantly slowed brain atrophy rates in comparison to INF- $\beta 1$ a (baseline to 96 weeks: $23.5 \% \mathrm{p}<0.0001$ in OPERA 1 and $23.8 \% \mathrm{p}<0.0001$ in OPERA 2) along with clinical disability [154]. Ocrelizumab reduced the rate of whole BVL in PPMS from week 24 to week 120 by $17.5 \% 120$ $(\mathrm{p}=0.0206)$ compared with placebo (ORATORIO) [155].

\section{Emerging DMTs and their effect on PBVC}

Several new agents are currently undergoing clinical development, including immuno-modulatory, neuroprotective or remyelinating compounds.

Laquinimod, a linomide derivative, has also shown promising results on PVC rates in RRMS, most probably 
as a result of reduced astrocytic activation within the CNS [156]. In the ALLEGRO clinical trial, after adjusting for baseline active inflammation, laquinimod markedly reduced BVL as compared to the placebo [157]. Positive effects on PBVC are replicated in one active comparator trial [BRAVO] versus im IFN- $\beta-1 \mathrm{a}[158,159]$. At present, the agent is further investigated in RRMS [CONCERTO] and PPMS patients [ARPEGGIO].

Cladribine, an antiproliferative agent that takes effect by interfering with DNA synthesis, has shown significant effects in terms of relapse rate and disability progression $[160,161]$. Data from CLARITY study suggested that at 18 months, patients treated with cladribine had $20 \%$ reduction in brain atrophy compared with patients receiving placebo [162]. However, further studies are needed, in order to cladribine's effect on brain atrophy rates, be fully elucidated $[161,163,164]$.

\section{Conclusions}

MS is an evolving disease, now considered of both inflammatory and neurodegenerative nature [165-168]. Axonal injury and loss accounting for brain atrophy may be either acute (i.e. due to inflammation) or chronic/late due to pathogenic mechanisms primed by the preceding inflammation and later perpetuating with disease progression [169-171]. Brain atrophy occurs as early as CIS, progresses faster than it does in healthy adults, and is the best predictor of future disability, physical and cognitive $[166,172]$. It is widely accepted to be a valid, sensitive and reproducible measure of neuroprotection in MS research studies and therapeutic trials.

There is now a variety of approved DMDs, with secondary neuroprotective properties, and an even greater number of novel compounds, in various stages of development and investigation. A firm belief remains that for a therapy to be effective in delaying the disease progression, its impact on axon and neuronal survival needs to be monitored. Conventional MRI findings (T1-hypotensive or T2 hypertensive lesion load) have already shown their limits for monitoring the disease burden and progression in MS patients. Newly introduced sophisticated imaging methods hold promise for the future of the clinical surveillance of the disease. Trials incorporating brain atrophy in their endpoints are providing accumulating evidence that rises substantial hopes for treating neurodegeneration in the near future.

\section{Acknowledgements}

Not applicable

\section{Authors' contributions}

$A A, E D, A A, M S, V S, G M H$ were involved in the conception of the study. $A A$, $E D, A A, M S, V S, G M H, Z T$, AMA, IN, CB, GT, GD, NG, DPB were involved in the acquisition of the data and study design. AA, ED, AA, MS, VS, GMH, ZT, AMA, IN, $C B, G T, G D, N G$, DPB were involved in the writing of the article. $A A, E D, A A, M S$,
VS, GMH, ZT, AMA, IN, CB, GT, GD, NG, DPB critically revised the manuscript. All authors read and approved the final manuscript.

Funding

The author(s) received no specific funding for this work.

\section{Ethics approval and consent to participate}

Compliance with ethical standards. Human and animal rights: This article does not contain any studies with animals performed by any of the authors. This article does not require informed consent due to the lack of human participants.

\section{Consent for publication}

This article does not require informed consent due to the lack of human participants.

\section{Competing interests}

The authors declare that they have no competing interests.

\section{Author details}

${ }^{1}$ Department of Neurology, Laboratory of Neurogenetics, Faculty of Medicine, University of Thessaly, University Hospital of Larissa, Biopolis, Mezourlo Hill, 41100 Larissa, Greece. ${ }^{2}$ Immunogenetics Laboratory, 1st Department of Neurology, Medical School, National and Kapodistrian University of Athens, Aeginition Hospital, Vas. Sophias Ave 72-74, 11528 Athens, Greece. ${ }^{3}$ Department of Rheumatology and Clinical Immunology, Faculty of Medicine, School of Health Sciences, University General Hospital of Larissa, University of Thessaly, Viopolis, 40500 Larissa, Greece. ${ }^{4}$ Multiple Sclerosis Center, 2nd Department of Neurology, AHEPA University Hospital, Aristotle University of Thessaloniki, Thessaloniki, Greece. ${ }^{5}$ Second Department of Neurology, School of Medicine, University of Athens, "Attikon" University Hospital, Athens, Greece. ${ }^{6}$ Department of Neurology, Papageorgiou General Hospital, Thessaloniki, Greece. ${ }^{7}$ Department of Neurology, Medical School, University of Cyprus, Nicosia, Cyprus.

Received: 13 March 2019 Accepted: 28 June 2019

Published online: 10 August 2019

\section{References}

1. Vasileiadis GK, Dardiotis E, Mavropoulos A, Tsouris Z, Tsimourtou V, Bogdanos DP, Sakkas LI, Hadjigeorgiou GM. Regulatory B and T lymphocytes in multiple sclerosis: friends or foes? Auto Immun Highlights. 2018;9(1):9. https://doi.org/10.1007/s13317-018-0109-x.

2. Mitrovič M, Patsopoulos NA, Beecham AH, Dankowski T, Goris A, Dubois B, D'hooghe MB, Lemmens R, Van Damme P, Søndergaard HB, Sellebjerg F. Low-frequency and rare-coding variation contributes to multiple sclerosis risk. Cell. 2018;175(6):1679-1687.e1677. https://doi. org/10.1016/j.cell.2018.09.049.

3. Hadjigeorgiou GM, Kountra PM, Koutsis G, Tsimourtou V, Siokas V, Dardioti M, Rikos D, Marogianni C, Aloizou AM, Karadima G, Ralli S, Grigoriadis N, Bogdanos D, Panas M, Dardiotis E. Replication study of GWAS risk loci in Greek multiple sclerosis patients. Neurol Sci. 2018. https://doi.org/10.1007/s10072-018-3617-6.

4. Kutzelnigg A, Lucchinetti CF, Stadelmann C, Bruck W, Rauschka H, Bergmann M, Schmidbauer M, Parisi JE, Lassmann H. Cortical demyelination and diffuse white matter injury in multiple sclerosis. Brain. 2005;128(Pt 11):2705-12. https://doi.org/10.1093/brain/awh641.

5. Lycklama A, Nijeholt GJ. Reduction of brain volume in MS. MRI and pathology findings. J Neurol Sci. 2005;233(1-2):199-202. https://doi. org/10.1016/j.jns.2005.03.016.

6. Giovannoni G, Butzkueven H, Dhib-Jalbut S, Hobart J, Kobelt G, Pepper G, Sormani MP, Thalheim C, Traboulsee A, Vollmer T. Brain health: time matters in multiple sclerosis. Mult Scler Relat Disord. 2016;9:S5-48.

7. Calabrese M, Atzori M, Bernardi V, Morra A, Romualdi C, Rinaldi L, McAuliffe MJ, Barachino L, Perini P, Fischl B, Battistin L, Gallo P. Cortical atrophy is relevant in multiple sclerosis at clinical onset. J Neurol. 2007;254(9):1212-20. https://doi.org/10.1007/s00415-006-0503-6.

8. Paolillo A, Pozzilli C, Gasperini C, Giugni E, Mainero C, Giuliani S, Tomassini V, Millefiorini E, Bastianello S. Brain atrophy in 
relapsing-remitting multiple sclerosis: relationship with 'black holes', disease duration and clinical disability. J Neurol Sci. 2000;174(2):85-91.

9. Ferguson B, Matyszak MK, Esiri MM, Perry VH. Axonal damage in acute multiple sclerosis lesions. Brain. 1997;120(Pt 3):393-9.

10. BruckW. The pathology of multiple sclerosis is the result of focal inflammatory demyelination with axonal damage. J Neurol. 2005;252(Suppl 5):v3-9. https://doi.org/10.1007/s00415-005-5002-7.

11. Jacobsen C, Hagemeier J, Myhr KM, Nyland H, Lode K, Bergsland N, Ramasamy DP, Dalaker TO, Larsen JP, Farbu E, Zivadinov R. Brain atrophy and disability progression in multiple sclerosis patients: a 10-year follow-up study. J Neurol Neurosurg Psychiatry. 2014;85(10):1109-15. https://doi.org/10.1136/jnnp-2013-306906.

12. Fisher $\mathrm{E}$, Lee JC, Nakamura K, Rudick RA. Gray matter atrophy in multiple sclerosis: a longitudinal study. Ann Neurol. 2008;64(3):255-65. https:// doi.org/10.1002/ana.21436.

13. Tsivgoulis G, Katsanos AH, Grigoriadis N, Hadjigeorgiou GM, Heliopoulos I, Papathanasopoulos P, Dardiotis E, Kilidireas C, Voumvourakis $K$. The effect of disease-modifying therapies on brain atrophy in patients with clinically isolated syndrome: a systematic review and meta-analysis. Ther Adv Neurol Disord. 2015;8(5):193-202. https://doi. org/10.1177/1756285615600381.

14. Bermel RA, Bakshi R. The measurement and clinical relevance of brain atrophy in multiple sclerosis. Lancet Neurol. 2006;5(2):158-70. https:// doi.org/10.1016/s1474-4422(06)70349-0.

15. Pelletier D, Garrison K, Henry R. Measurement of whole-brain atrophy in multiple sclerosis. J Neuroimaging. 2004;14(3 Suppl):11s-9s. https://doi. org/10.1177/1051228404266264.

16. Riley C, Azevedo C, Bailey M, Pelletier D. Clinical applications of imaging disease burden in multiple sclerosis: MRI and advanced imaging techniques. Expert Rev Neurother. 2012;12(3):323-33. https://doi. org/10.1586/ern.11.196.

17. Ghione E, Bergsland N, Dwyer MG, Hagemeier J, Jakimovski D, Paunkoski I, Ramasamy DP, Silva D, Carl E, Hojnacki D, Kolb C, WeinstockGuttman B, Zivadinov R. Brain atrophy is associated with disability progression in patients with MS followed in a clinical routine. AJNR Am J Neuroradiol. 2018;39(12):2237-42. https://doi.org/10.3174/ajnr. A5876.

18. Chard D, Miller D. Grey matter pathology in clinically early multiple sclerosis: evidence from magnetic resonance imaging. J Neurol Sci. 2009;282(1-2):5-11. https://doi.org/10.1016/j.jns.2009.01.012.

19. Pelvig DP, Pakkenberg H, Stark AK, Pakkenberg B. Neocortical glial cell numbers in human brains. Neurobiol Aging. 2008;29(11):1754-62. https ://doi.org/10.1016/j.neurobiolaging.2007.04.013.

20. von Bartheld CS, Bahney J, Herculano-Houzel S. The search for true numbers of neurons and glial cells in the human brain: a review of 150 years of cell counting. J Comp Neurol. 2016;524(18):3865-95.

21. Filippi M, Charil A, Rovaris M, Absinta M, Rocca MA. Insights from magnetic resonance imaging. Handb Clin Neurol. 2014;122:115-49. https:// doi.org/10.1016/b978-0-444-52001-2.00006-6.

22. Chu R, Kim G, Tauhid S, Khalid F, Healy BC, Bakshi R. Whole brain and deep gray matter atrophy detection over 5 years with 3T MRI in multiple sclerosis using a variety of automated segmentation pipelines. PLOS ONE. 2018;13(11):e0206939. https://doi.org/10.1371/journal.pone.0206939.

23. Amiri $H$, de Sitter A, Bendfeldt K, Battaglini M, Gandini WheelerKingshott CAM, Calabrese M, Geurts JJG, Rocca MA, Sastre-Garriga J, Enzinger C, de Stefano N, Filippi M, Rovira A, Barkhof F, Vrenken H. Urgent challenges in quantification and interpretation of brain grey matter atrophy in individual MS patients using MRI. Neuroimage Clin. 2018;19:466-75. https://doi.org/10.1016/j.nicl.2018.04.023.

24. Miller DH, Barkhof F, Frank JA, Parker GJ, Thompson AJ. Measurement of atrophy in multiple sclerosis: pathological basis, methodological aspects and clinical relevance. Brain. 2002;125(Pt 8):1676-95.

25. Anderson VM, Fox NC, Miller DH. Magnetic resonance imaging measures of brain atrophy in multiple sclerosis. J Magn Reson Imaging. 2006;23(5):605-18. https://doi.org/10.1002/jmri.20550.

26. Zivadinov R, Reder AT, Filippi M, Minagar A, Stuve O, Lassmann H, Racke MK, Dwyer MG, Frohman EM, Khan O. Mechanisms of action of diseasemodifying agents and brain volume changes in multiple sclerosis. Neurology. 2008;71(2):136-44. https://doi.org/10.1212/01.wnl.00003 16810.01120 .05
27. Dutta R, Trapp BD. Pathogenesis of axonal and neuronal damage in multiple sclerosis. Neurology. 2007;68(22 Suppl 3):S22-31. https://doi. org/10.1212/01.wnl.0000275229.13012.32 (Discussion S43-54).

28. Neacsu V, Jasperse B, Korteweg T, Knol DL, Valsasina P, Filippi M, Barkhof $F$, Rovaris $M$, Vrenken $H$. Agreement between different input image types in brain atrophy measurement in multiple sclerosis using SIENAX and SIENA. J Magn Reson Imaging. 2008;28(3):559-65.

29. Saidha S, Al-Louzi O, Ratchford JN, Bhargava P, Oh J, Newsome SD, Prince JL, Pham D, Roy S, Van Zijl P. Optical coherence tomography reflects brain atrophy in multiple sclerosis: a four-year study. Ann Neurol. 2015;78(5):801-13.

30. Ruberte E, Sinnecker T, Amann M, Gaetano L, Naegelin Y, Penner IK, Kuhle J, Derfuss T, Kappos L, Granziera C, Wuerfel J, Yaldizli O. Central slab versus whole brain to measure brain atrophy in multiple sclerosis. Eur Neurol. 2019;80(3-4):207-14. https://doi.org/10.1159/000495798.

31. Lorefice L, Fenu G, Sardu C, Frau J, Coghe G, Costa G, Schirru L, Secci MA, Sechi V, Barracciu MA, Marrosu MG, Cocco E. Multiple sclerosis and HLA genotypes: a possible influence on brain atrophy. Mult Scler. 2017. https://doi.org/10.1177/1352458517739989.

32. Brex PA, Ciccarelli O, O'Riordan JI, Sailer M, Thompson AJ, Miller DH. A longitudinal study of abnormalities on MRI and disability from multiple sclerosis. N Engl J Med. 2002;346(3):158-64. https://doi.org/10.1056/ NEJMoa011341.

33. Tedeschi G, Lavorgna L, Russo P, Prinster A, Dinacci D, Savettieri G, Quattrone A, Livrea P, Messina C, Reggio A, Bresciamorra V, Orefice G, Paciello M, Brunetti A, Coniglio G, Bonavita S, Di Costanzo A, Bellacosa A, Valentino P, Quarantelli M, Patti F, Salemi G, Cammarata E, Simone IL, Salvatore M, Bonavita V, Alfano B. Brain atrophy and lesion load in a large population of patients with multiple sclerosis. Neurology. 2005;65(2):280-5. https://doi.org/10.1212/01.wnl.0000168837.87351.1f.

34. Dalton CM, Chard DT, Davies GR, Miszkiel KA, Altmann DR, Fernando K, Plant GT, Thompson AJ, Miller DH. Early development of multiple sclerosis is associated with progressive grey matter atrophy in patients presenting with clinically isolated syndromes. Brain. 2004;127(Pt 5):1101-7. https://doi.org/10.1093/brain/awh126.

35. Meier DS, Weiner HL, Khoury SJ, Guttmann CR. Magnetic resonance imaging surrogates of multiple sclerosis pathology and their relationship to central nervous system atrophy. J Neuroimaging. 2004;14(3 Suppl):46s-53s. https://doi.org/10.1177/1051228404266268.

36. Pelletier D, Nelson SJ, Oh J, Antel JP, Kita M, Zamvil SS, Goodkin DE. MRI lesion volume heterogeneity in primary progressive MS in relation with axonal damage and brain atrophy. J Neurol Neurosurg Psychiatry. 2003;74(7):950-2.

37. Chard DT, Brex PA, Ciccarelli O, Griffin CM, Parker GJ, Dalton C, Altmann DR, Thompson AJ, Miller DH. The longitudinal relation between brain lesion load and atrophy in multiple sclerosis: a 14 year follow up study. J Neurol Neurosurg Psychiatry. 2003;74(11):1551-4.

38. Chard DT, Griffin CM, Parker GJ, Kapoor R, Thompson AJ, Miller DH. Brain atrophy in clinically early relapsing-remitting multiple sclerosis. Brain. 2002;125(Pt 2):327-37.

39. Hochmeister S, Grundtner R, Bauer J, Engelhardt B, Lyck R, Gordon G, Korosec T, Kutzelnigg A, Berger JJ, Bradl M, Bittner RE, Lassmann $H$. Dysferlin is a new marker for leaky brain blood vessels in multiple sclerosis. J Neuropathol Exp Neurol. 2006;65(9):855-65. https://doi. org/10.1097/01.jnen.0000235119.52311.16.

40. Trapp BD, Vignos M, Dudman J, Chang A, Fisher E, Staugaitis SM, Battapady H, Mork S, Ontaneda D, Jones SE. Cortical neuronal densities and cerebral white matter demyelination in multiple sclerosis: a retrospective study. Lancet Neurol. 2018;17(10):870-84.

41. Eshaghi A, Prados F, Brownlee WJ, Altmann DR, Tur C, Cardoso MJ, De Angelis F, van de Pavert SH, Cawley N, De Stefano N, Stromillo ML, Battaglini M, Ruggieri S, Gasperini C, Filippi M, Rocca MA, Rovira A Sastre-Garriga J, Vrenken H, Leurs CE, Killestein J, Pirpamer L, Enzinger C, Ourselin S, Wheeler-Kingshott C, Chard D, Thompson AJ, Alexander DC, Barkhof F, Ciccarelli O. Deep gray matter volume loss drives disability worsening in multiple sclerosis. Ann Neurol. 2018;83(2):210-22. https:// doi.org/10.1002/ana.25145.

42. Pagani E, Rocca MA, Gallo A, Rovaris M, Martinelli V, Comi G, Filippi M. Regional brain atrophy evolves differently in patients with multiple sclerosis according to clinical phenotype. AJNR Am J Neuroradiol. 2005;26(2):341-6. 
43. Minagar A, Toledo EG, Alexander JS, Kelley RE. Pathogenesis of brain and spinal cord atrophy in multiple sclerosis. J Neuroimaging. 2004;14(3 Suppl):5s-10s. https://doi.org/10.1177/1051228404266263.

44. Mahad DH, Trapp BD, Lassmann H. Pathological mechanisms in progressive multiple sclerosis. Lancet Neurol. 2015;14(2):183-93.

45. Noseworthy JH, Lucchinetti C, Rodriguez M, Weinshenker BG. Multiple sclerosis. N Engl J Med. 2000;343(13):938-52. https://doi.org/10.1056/ nejm200009283431307.

46. Popescu BFG, Lucchinetti CF. Meningeal and cortical grey matter pathology in multiple sclerosis. BMC Neurol. 2012;12(1):11.

47. Häusser-Kinzel S, Weber MS. The role of B cells and antibodies in multiple sclerosis, neuromyelitis optica, and related disorders. Front Immunol. 2019;10:201.

48. Lassmann $\mathrm{H}$, van Horssen J, Mahad D. Progressive multiple sclerosis: pathology and pathogenesis. Nat Rev Neurol. 2012;8(11):647-56. https ://doi.org/10.1038/nrneurol.2012.168.

49. Dutta R, Trapp BD. Mechanisms of neuronal dysfunction and degeneration in multiple sclerosis. Prog Neurobiol. 2011;93(1):1-12. https://doi. org/10.1016/j.pneurobio.2010.09.005.

50. Ellwardt E, Zipp F. Molecular mechanisms linking neuroinflammation and neurodegeneration in MS. Exp Neurol. 2014;262(Pt A):8-17. https:// doi.org/10.1016/j.expneurol.2014.02.006

51. Lucchinetti C, Bruck W, Parisi J, Scheithauer B, Rodriguez M, Lassmann $H$. Heterogeneity of multiple sclerosis lesions: implications for the pathogenesis of demyelination. Ann Neurol. 2000;47(6):707-17.

52. Metz I, Weigand SD, Popescu BF, Frischer JM, Parisi JE, Guo Y, Lassmann $\mathrm{H}$, Bruck W, Lucchinetti CF. Pathologic heterogeneity persists in early active multiple sclerosis lesions. Ann Neurol. 2014;75(5):728-38. https:// doi.org/10.1002/ana.24163.

53. Barnett $\mathrm{MH}$, Prineas JW. Relapsing and remitting multiple sclerosis: pathology of the newly forming lesion. Ann Neurol. 2004;55(4):458-68. https://doi.org/10.1002/ana.20016.

54. Enzinger C, Ropele S, Smith S, Strasser-Fuchs S, Poltrum B, Schmidt $H$, Matthews PM, Fazekas F. Accelerated evolution of brain atrophy and "black holes" in MS patients with APOE-epsilon 4. Ann Neurol. 2004;55(4):563-9. https://doi.org/10.1002/ana.20027.

55. Koudriavtseva T, Mainero C. Neuroinflammation, neurodegeneration and regeneration in multiple sclerosis: intercorrelated manifestations of the immune response. Neural Regen Res. 2016;11(11):1727.

56. Filippi M, Rocca MA. MR imaging of multiple sclerosis. Radiology 2011;259(3):659-81. https://doi.org/10.1148/radiol.11101362.

57. Trapp BD, Nave KA. Multiple sclerosis: an immune or neurodegenerative disorder? Annu Rev Neurosci. 2008;31:247-69. https://doi.org/10.1146/ annurev.neuro.30.051606.094313.

58. Mahad D, Ziabreva I, Lassmann H, Turnbull D. Mitochondrial defects in acute multiple sclerosis lesions. Brain. 2008;131(Pt 7):1722-35. https:// doi.org/10.1093/brain/awn105.

59. Kuhle J, Kropshofer H, Haering DA, Kundu U, Meinert R, Barro C, Dahlke F, Tomic D, Leppert D, Kappos L. Blood neurofilament light chain as a biomarker of MS disease activity and treatment response. Neurology. 2019;92(10):e1007-15. https://doi.org/10.1212/wnl.0000000000007032.

60. Lubetzki C, Stankoff B. Demyelination in multiple sclerosis. Handb Clin Neurol. 2014;122:89-99. https://doi.org/10.1016/b978-0-444-52001 $-2.00004-2$.

61. Waxman SG, Craner MJ, Black JA. Na + channel expression along axons in multiple sclerosis and its models. Trends Pharmacol Sci. 2004;25(11):584-91. https://doi.org/10.1016/j.tips.2004.09.001.

62. Desmazieres A, Sol-Foulon N, Lubetzki C. Changes at the nodal and perinodal axonal domains: a basis for multiple sclerosis pathology? Mult Scler. 2012;18(2):133-7. https://doi.org/10.1177/135245851143437 0 .

63. Fischer MT, Sharma R, Lim JL, Haider L, Frischer JM, Drexhage J, Mahad D, Bradl M, van Horssen J, Lassmann H. NADPH oxidase expression in active multiple sclerosis lesions in relation to oxidative tissue damage and mitochondrial injury. Brain. 2012;135(Pt 3):886-99. https://doi. org/10.1093/brain/aws012.

64. Campbell GR, Mahad DJ. Mitochondria as crucial players in demyelinated axons: lessons from neuropathology and experimental demyelination. Autoimmune Dis. 2011;2011:262847. https://doi. org/10.4061/2011/262847
65. Witte ME, Mahad DJ, Lassmann $\mathrm{H}$, van Horssen J Mitochondrial dysfunction contributes to neurodegeneration in multiple sclerosis. Trends Mol Med. 2014;20(3):179-87. https://doi.org/10.1016/j.molme d.2013.11.007.

66. Zambonin JL, Zhao C, Ohno N, Campbell GR, Engeham S, Ziabreva I, Schwarz N, Lee SE, Frischer JM, Turnbull DM, Trapp BD, Lassmann H, Franklin RJ, Mahad DJ. Increased mitochondrial content in remyelinated axons: implications for multiple sclerosis. Brain. 2011;134(Pt 7):1901-13. https://doi.org/10.1093/brain/awr110.

67. Campbell GR, Ziabreva I, Reeve AK, Krishnan KJ, Reynolds R, Howell O, Lassmann H, Turnbull DM, Mahad DJ. Mitochondrial DNA deletions and neurodegeneration in multiple sclerosis. Ann Neurol. 2011;69(3):48192. https://doi.org/10.1002/ana.22109.

68. Mao P, Reddy PH. Is multiple sclerosis a mitochondrial disease? Biochimica et biophysica acta 1802. Biochim Biophys Acta. 2010;1:66-79. https://doi.org/10.1016/j.bbadis.2009.07.002.

69. Carvalho KS. Mitochondrial dysfunction in demyelinating diseases. Semin Pediatr Neurol. 2013;20(3):194-201. https://doi.org/10.1016/j. spen.2013.09.001.

70. Filippi M, Rocca MA, Barkhof F, Bruck W, Chen JT, Comi G, DeLuca G, De Stefano N, Erickson BJ, Evangelou N, Fazekas F, Geurts JJ, Lucchinetti C, Miller DH, Pelletier D, Popescu BF, Lassmann H. Association between pathological and MRI findings in multiple sclerosis. Lancet Neurol. 2012;11(4):349-60. https://doi.org/10.1016/s1474-4422(12)70003-0.

71. Bakshi R, Shaikh ZA, Janardhan V. MRI T2 shortening ('black T2') in multiple sclerosis: frequency, location, and clinical correlation. NeuroReport. 2000:11(1):15-21.

72. Bermel RA, Puli SR, Rudick RA, Weinstock-Guttman B, Fisher E, Munschauer FE 3rd, Bakshi R. Prediction of longitudinal brain atrophy in multiple sclerosis by gray matter magnetic resonance imaging T2 hypointensity. Arch Neurol. 2005;62(9):1371-6. https://doi.org/10.1001/ archneur.62.9.1371.

73. Ceccarelli A, Rocca MA, Perego E, Moiola L, Ghezzi A, Martinelli V, Comi G, Filippi M. Deep grey matter T2 hypo-intensity in patients with paediatric multiple sclerosis. Mult Scler. 2011;17(6):702-7. https://doi. org/10.1177/1352458510395645.

74. Stankiewicz JM, Neema M, Ceccarelli A. Iron and multiple sclerosis. Neurobiology of aging 35. Supplement. 2014;2:S51-8. https://doi. org/10.1016/j.neurobiolaging.2014.03.039.

75. Stephenson E, Nathoo N, Mahjoub Y, Dunn JF, Yong VW. Iron in multiple sclerosis: roles in neurodegeneration and repair. Nat Rev Neurol. 2014:10(8):459-68. https://doi.org/10.1038/nrneurol.2014.118.

76. Stojanovic IR, Kostic M, Ljubisavljevic S. The role of glutamate and its receptors in multiple sclerosis. J Neural Transm. 2014;121(8):945-55. https://doi.org/10.1007/s00702-014-1188-0.

77. Sarchielli P, Greco L, Floridi A, Floridi A, Gallai V. Excitatory amino acids and multiple sclerosis: evidence from cerebrospinal fluid. Arch Neurol. 2003;60(8):1082-8. https://doi.org/10.1001/archneur.60.8.1082.

78. Geurts JJ, Wolswijk G, Bo L, van der Valk P, Polman CH, Troost D, Aronica E. Altered expression patterns of group I and II metabotropic glutamate receptors in multiple sclerosis. Brain. 2003;126(Pt 8):1755-66. https:// doi.org/10.1093/brain/awg179.

79. Srinivasan R, Sailasuta N, Hurd R, Nelson S, Pelletier D. Evidence of elevated glutamate in multiple sclerosis using magnetic resonance spectroscopy at 3 T. Brain. 2005;128(Pt 5):1016-25. https://doi. org/10.1093/brain/awh467.

80. Papathanasiou A, Messinis L, Zampakis P, Panagiotakis G, Gourzis P, Georgiou V, Papathanasopoulos P. Thalamic atrophy predicts cognitive impairment in relapsing remitting multiple sclerosis. Effect on instrumental activities of daily living and employment status. J Neurol Sci. 2015;358(1-2):236-42.

81. Barkhof F. The clinico-radiological paradox in multiple sclerosis revisited Curr Opin Neurol. 2002;15(3):239-45.

82. Healy BC, Buckle GJ, Ali EN, Egorova S, Khalid F, Tauhid S, Glanz BI, Chitnis T, Guttmann CR, Weiner HL. Characterizing clinical and MRI dissociation in patients with multiple sclerosis. J Neuroimaging. 2017;27(5):481-5.

83. Rudick RA, Fisher E, Lee JC, Duda JT, Simon J. Brain atrophy in relapsing multiple sclerosis: relationship to relapses, EDSS, and treatment with interferon beta-1a. Mult Scler. 2000;6(6):365-72. 
84. Fisher E, Rudick RA, Simon JH, Cutter G, Baier M, Lee JC, Miller D, Weinstock-Guttman B, Mass MK, Dougherty DS, Simonian NA. Eightyear follow-up study of brain atrophy in patients with MS. Neurology. 2002;59(9):1412-20.

85. Zivadinov R, Bakshi R. Central nervous system atrophy and clinical status in multiple sclerosis. J Neuroimaging. 2004;14(3 Suppl):27s-35s. https://doi.org/10.1177/1051228404266266.

86. Sormani MP, Arnold DL, De Stefano N. Treatment effect on brain atrophy correlates with treatment effect on disability in multiple sclerosis. Ann Neurol. 2014;75(1):43-9. https://doi.org/10.1002/ana.24018.

87. Rudick RA, Fisher E, Lee JC, Simon J, Jacobs L. Use of the brain parenchymal fraction to measure whole brain atrophy in relapsing-remitting MS. Multiple Sclerosis Collaborative Research Group. Neurology. 1999;53(8):1698-704.

88. Rocca MA, Comi G, Filippi M. The role of T1-weighted derived measures of neurodegeneration for assessing disability progression in multiple sclerosis. Front Neurol. 2017;8:433.

89. Zivadinov R, Uher T, Hagemeier J, Vaneckova M, Ramasamy DP, Tyblova M, Bergsland N, Seidl Z, Dwyer MG, Krasensky J, Havrdova E, Horakova D. A serial 10-year follow-up study of brain atrophy and disability progression in RRMS patients. Mult Scler. 2016;22(13):1709-18. https://doi. org/10.1177/1352458516629769.

90. Rojas Jl, Patrucco L, Besada C, Bengolea L, Cristiano E. Brain atrophy at onset and physical disability in multiple sclerosis. Arq Neuropsiquiatr. 2012;70(10):765-8.

91. Samann PG, Knop M, Golgor E, Messler S, Czisch M, Weber F. Brain volume and diffusion markers as predictors of disability and shortterm disease evolution in multiple sclerosis. AJNR Am J Neuroradiol. 2012;33(7):1356-62. https://doi.org/10.3174/ajnr.A2972.

92. Fragoso YD, Wille PR, Abreu M, Brooks JBB, Dias RM, Duarte JA, Farage L, Finkelsztejn A, Frohlich AC, Goncalves MVM, Guedes BVS, Medeiros L, Oliveira RA, Ribas FD, da Rocha FCG, Santos GAC, Scorcine C, da Silveira GL, Spedo CT, Tauil CB, Varela JS, Vieira VLF. Correlation of clinical findings and brain volume data in multiple sclerosis. J Clin Neurosci. 2017:44:155-7. https://doi.org/10.1016/j.jocn.2017.06.006.

93. Pichler A, Khalil M, Langkammer C, Pinter D, Bachmaier G, Ropele S, Fuchs S, Enzinger C, Fazekas F. Combined analysis of global and compartmental brain volume changes in early multiple sclerosis in clinical practice. Mult Scler. 2016;22(3):340-6. https://doi.org/10.1177/13524 58515593405

94. Bakirtzis C, loannidis P, Messinis L, Nasios G, Konstantinopoulou E, Papathanasopoulos P, Grigoriadis N. The rationale for monitoring cognitive function in multiple sclerosis: practical issues for clinicians. Open Neurol J. 2018;12:31-40. https://doi.org/10.2174/1874205x01812010031.

95. Anhoque CF, Biccas Neto L, Domingues SCA, Teixeira AL, Domingues RB. Cognitive impairment in patients with clinically isolated syndrome. Dement Neuropsychol. 2012:6:266-9.

96. Zivadinov R, Sepcic J, Nasuelli D, De Masi R, Bragadin LM, Tommasi MA, Zambito-Marsala S, Moretti R, Bratina A, Ukmar M, Pozzi-Mucelli RS, Grop A, Cazzato G, Zorzon M. A longitudinal study of brain atrophy and cognitive disturbances in the early phase of relapsing-remitting multiple sclerosis. J Neurol Neurosurg Psychiatry. 2001;70(6):773-80.

97. Calabrese M, Rinaldi F, Mattisi I, Grossi P, Favaretto A, Atzori M, Bernardi V, Barachino L, Romualdi C, Rinaldi L, Perini P, Gallo P. Widespread cortical thinning characterizes patients with MS with mild cognitive impairment. Neurology. 2010;74(4):321-8. https://doi.org/10.1212/WNL.0b013 e3181cbcd03.

98. Pravata E, Rocca MA, Valsasina P, Riccitelli GC, Gobbi C, Comi G, Falini A, Filippi M. Gray matter trophism, cognitive impairment, and depression in patients with multiple sclerosis. Mult Scler. 2017;23(14):1864-74. https://doi.org/10.1177/1352458517692886.

99. Houtchens MK, Benedict RH, Killiany R, Sharma J, Jaisani Z, Singh B, Weinstock-Guttman B, Guttmann CR, Bakshi R. Thalamic atrophy and cognition in multiple sclerosis. Neurology. 2007;69(12):1213-23. https:// doi.org/10.1212/01.wnl.0000276992.17011.b5.

100. Sumowski JF, Chiaravalloti N, Wylie G, Deluca J. Cognitive reserve moderates the negative effect of brain atrophy on cognitive efficiency in multiple sclerosis. J Int Neuropsychol Soc. 2009;15(4):606-12. https:// doi.org/10.1017/s1355617709090912.

101. Benedict RH, Wahlig E, Bakshi R, Fishman I, Munschauer F, Zivadinov $R$, Weinstock-Guttman B. Predicting quality of life in multiple sclerosis: accounting for physical disability, fatigue, cognition, mood disorder, personality, and behavior change. J Neurol Sci. 2005;231(1-2):29-34. https://doi.org/10.1016/j.jns.2004.12.009.

102. Sepulcre J, Masdeu JC, Goni J, Arrondo G, Velez de Mendizabal N, Bejarano $B$, Villoslada $P$. Fatigue in multiple sclerosis is associated with the disruption of frontal and parietal pathways. Mult Scler. 2009;15(3):33744. https://doi.org/10.1177/1352458508098373.

103. Luessi F, Siffrin V, Zipp F. Neurodegeneration in multiple sclerosis: novel treatment strategies. Expert Rev Neurother. 2012;12(9):1061-76. https:// doi.org/10.1586/ern.12.59 (quiz 1077).

104. Fisher E, Nakamura K, Lee JC, You X, Sperling B, Rudick RA. Effect of intramuscular interferon beta-1a on gray matter atrophy in relapsingremitting multiple sclerosis: a retrospective analysis. Mult Scler. 2016;22(5):668-76. https://doi.org/10.1177/1352458515599072.

105. De Stefano N, Comi G, Kappos L, Freedman MS, Polman CH, Uitdehaag BM, Hennessy B, Casset-Semanaz F, Lehr L, Stubinski B, Jack DL, Barkhof F. Efficacy of subcutaneous interferon beta-1a on MRI outcomes in a randomised controlled trial of patients with clinically isolated syndromes. J Neurol Neurosurg Psychiatry. 2014;85(6):647-53. https://doi. org/10.1136/jnnp-2013-306289.

106. Filippi M, Rovaris M, Inglese M, Barkhof F, De Stefano N, Smith S, Comi G. Interferon beta-1a for brain tissue loss in patients at presentation with syndromes suggestive of multiple sclerosis: a randomised, doubleblind, placebo-controlled trial. Lancet. 2004;364(9444):1489-96. https:// doi.org/10.1016/s0140-6736(04)17271-1.

107. Jones CK, Riddehough A, Li DKB, Zhao G, Paty DW, Group. atPS. MRI cerebral atrophy in relapsing-remitting MS: results from the PRISMS trial. Neurology. 2001;56(suppl 3):379 (abstr).

108. Kappos L, Traboulsee A, Constantinescu C, Eralinna JP, Forrestal F, Jongen P, Pollard J, Sandberg-Wollheim M, Sindic C, Stubinski B, Uitdehaag B, Li D. Long-term subcutaneous interferon beta-1a therapy in patients with relapsing-remitting MS. Neurology. 2006;67(6):944-53. https://doi. org/10.1212/01.wnl.0000237994.95410.ce.

109. Ravnborg M, Sorensen PS, Andersson M, Celius EG, Jongen PJ, Elovaara I, Bartholome E, Constantinescu CS, Beer K, Garde E, Sperling B. Methylprednisolone in combination with interferon beta-1a for relapsingremitting multiple sclerosis (MECOMBIN study): a multicentre, doubleblind, randomised, placebo-controlled, parallel-group trial. Lancet Neurol. 2010;9(7):672-80. https://doi.org/10.1016/s1474-4422(10)70132 -0 .

110. Sorensen PS, Mellgren SI, Svenningsson A, Elovaara I, Frederiksen UL, Beiske AG, Myhr KM, Sogaard LV, Olsen IC, Sandberg-Wollheim M. NORdic trial of oral Methylprednisolone as add-on therapy to Interferon beta-1a for treatment of relapsing-remitting Multiple Sclerosis (NORMIMS study): a randomised, placebo-controlled trial. Lancet Neurol. 2009;8(6):519-29. https://doi.org/10.1016/s1474-4422(09)70085-7.

111. Calabresi PA, Kieseier BC, Arnold DL, Balcer LJ, Boyko A, Pelletier J, Liu S, Zhu Y, Seddighzadeh A, Hung S, Deykin A. Pegylated interferon beta-1a for relapsing-remitting multiple sclerosis (ADVANCE): a randomised, phase 3, double-blind study. Lancet Neurol. 2014;13(7):657-65. https:// doi.org/10.1016/s1474-4422(14)70068-7.

112. Arnold DL, Kieseier BC, You X, Liu S, Sperling B, Hung S. Effects of Peginterferon Beta-1a on brain volume loss and magnetisation transfer ratio in patients with relapsing-remitting multiple sclerosis: 2-year advance results flash poster 2069. Eur J Neurol. 2015;22:614. https://doi. org/10.1111/ene.12808.

113. Comi G, Cohen JA, Arnold DL, Wynn D, Filippi M. Phase III dose-comparison study of glatiramer acetate for multiple sclerosis. Ann Neurol. 2011;69(1):75-82. https://doi.org/10.1002/ana.22316.

114. Comi G, Martinelli V, Rodegher M, Moiola L, Bajenaru O, Carra A, Elovaara I, Fazekas F, Hartung HP, Hillert J, King J, Komoly S, Lubetzki C, Montalban X, Myhr KM, Ravnborg M, Rieckmann P, Wynn D, Young C, Filippi M. Effect of glatiramer acetate on conversion to clinically definite multiple sclerosis in patients with clinically isolated syndrome (PreCISe study): a randomised, double-blind, placebo-controlled trial. Lancet. 2009;374(9700):1503-11. https://doi.org/10.1016/s0140-6736(09)61259 -9 .

115. Comi G, Martinelli V, Rodegher M, Moiola L, Leocani L, Bajenaru O, Carra A, Elovaara I, Fazekas F, Hartung HP, Hillert J, King J, Komoly S, Lubetzki C, Montalban X, Myhr KM, Preziosa P, Ravnborg M, Rieckmann P, Rocca MA, Wynn D, Young C, Filippi M. Effects of early treatment with 
glatiramer acetate in patients with clinically isolated syndrome. Mult Scler. 2013;19(8):1074-83. https://doi.org/10.1177/1352458512469695.

116. Ge Y, Grossman RI, Udupa JK, Fulton J, Constantinescu CS, GonzalesScarano F, Babb JS, Mannon LJ, Kolson DL, Cohen JA. Glatiramer acetate (Copaxone) treatment in relapsing-remitting MS: quantitative MR assessment. Neurology. 2000;54(4):813-7.

117. Khan O, Shen Y, Caon C, Bao F, Ching W, Reznar M, Buccheister A, Hu J, Latif Z, Tselis A, Lisak R. Axonal metabolic recovery and potential neuroprotective effect of glatiramer acetate in relapsing-remitting multiple sclerosis. Mult Scler. 2005;11 (6):646-51.

118. Rovaris M, Comi G, Rocca MA, Valsasina P, Ladkani D, Pieri E, Weiss S, Shifroni G, Wolinsky JS, Filippi M. Long-term follow-up of patients treated with glatiramer acetate: a multicentre, multinational extension of the European/Canadian double-blind, placebo-controlled, MRI-monitored trial. Mult Scler. 2007;13(4):502-8. https://doi.org/10.1177/1352458506 070704.

119. Rovaris M, Comi G, Rocca MA, Wolinsky JS, Filippi M. Short-term brain volume change in relapsing-remitting multiple sclerosis: effect of glatiramer acetate and implications. Brain. 2001;124(Pt 9):1803-12.

120. Calabresi PA, Radue EW, Goodin D, Jeffery D, Rammohan KW, Reder AT, Vollmer T, Agius MA, Kappos L, Stites T, Li B, Cappiello L, von Rosenstiel P, Lublin FD. Safety and efficacy of fingolimod in patients with relapsing-remitting multiple sclerosis (FREEDOMS II): a doubleblind, randomised, placebo-controlled, phase 3 trial. Lancet Neurol. 2014;13(6):545-56. https://doi.org/10.1016/s1474-4422(14)70049-3.

121. Cohen JA, Barkhof F, Comi G, Hartung HP, Khatri BO, Montalban X, Pelletier J, Capra R, Gallo P, Izquierdo G, Tiel-Wilck K, de Vera A, Jin J, Stites T, Wu S, Aradhye S, Kappos L. Oral fingolimod or intramuscular interferon for relapsing multiple sclerosis. N Engl J Med. 2010;362(5):402-15. https ://doi.org/10.1056/NEJMoa0907839.

122. Kappos L, Radue EW, O'Connor P, Polman C, Hohlfeld R, Calabresi P, Selmaj K, Agoropoulou C, Leyk M, Zhang-Auberson L, Burtin P. A placebo-controlled trial of oral fingolimod in relapsing multiple sclerosis. N Engl J Med. 2010;362(5):387-401. https://doi.org/10.1056/NEJMo a0909494.

123. Cohen JA, Khatri B, Barkhof F, Comi G, Hartung HP, Montalban X, Pelletier J, Stites T, Ritter S, von Rosenstiel P, Tomic D, Kappos L. Long-term (up to 4.5 years) treatment with fingolimod in multiple sclerosis: results from the extension of the randomised TRANSFORMS study. J Neurol Neurosurg Psychiatry. 2016;87(5):468-75. https://doi.org/10.1136/jnnp2015-310597.

124. Kappos L, O'Connor P, Radue EW, Polman C, Hohlfeld R, Selmaj K, Ritter S, Schlosshauer R, von Rosenstiel P, Zhang-Auberson L, Francis G. Long-term effects of fingolimod in multiple sclerosis: the randomized FREEDOMS extension trial. Neurology. 2015;84(15):1582-91. https://doi. org/10.1212/wnl.0000000000001462.

125. Khatri B, Barkhof F, Comi G, Hartung HP, Kappos L, Montalban X, Pelletier J, Stites T, Wu S, Holdbrook F, Zhang-Auberson L, Francis G, Cohen JA. Comparison of fingolimod with interferon beta-1a in relapsing-remitting multiple sclerosis: a randomised extension of the TRANSFORMS study. Lancet Neurol. 2011;10(6):520-9. https://doi.org/10.1016/s1474 $-4422(11) 70099-0$

126. Lublin F, Miller DH, Freedman MS, Cree BA, Wolinsky JS, Weiner $\mathrm{H}_{\text {, }}$ Lubetzki C, Hartung HP, Montalban X, Uitdehaag BM, Merschhemke M, Li B, Putzki N, Liu FC, Haring DA, Kappos L. Oral fingolimod in primary progressive multiple sclerosis (INFORMS): a phase 3, randomised, double-blind, placebo-controlled trial. Lancet. 2016;387(10023):107584. https://doi.org/10.1016/s0140-6736(15)01314-8.

127. Yousuf F, Dupuy SL, Tauhid S, Chu R, Kim G, Tummala S, Khalid F, Weiner HL, Chitnis T, Healy BC, Bakshi R. A two-year study using cerebral gray matter volume to assess the response to fingolimod therapy in multiple sclerosis. J Neurol Sci. 2017;383:221-9. https://doi.org/10.1016/j. jns.2017.10.019.

128. Khalil M, Enzinger C, Langkammer C, Petrovic K, Loitfelder M, Tscherner M, Jehna M, Bachmaier G, Wallner-Blazek M, Ropele S. Cognitive impairment in relation to MRI metrics in patients with clinically isolated syndrome. Mult Scler J. 2011;17(2):173-80.

129. Miller AE, Wolinsky JS, Kappos L, Comi G, Freedman MS, Olsson TP, Bauer D, Benamor M, Truffinet P, O'Connor PW. Oral teriflunomide for patients with a first clinical episode suggestive of multiple sclerosis (TOPIC): a randomised, double-blind, placebo-controlled, phase 3 trial. Lancet Neurol. 2014;13(10):977-86. https://doi.org/10.1016/s1474 $-4422(14) 70191-7$.

130. O'Connor P, Wolinsky JS, Confavreux C, Comi G, Kappos L, Olsson TP, Benzerdjeb H, Truffinet P, Wang L, Miller A, Freedman MS. Randomized trial of Oral teriflunomide for relapsing multiple sclerosis. N Engl J Med. 2011;365(14):1293-303. https://doi.org/10.1056/NEJMoa1014656.

131. Wolinsky JS, Narayana PA, Nelson F, Datta S, O'Connor P, Confavreux C, Comi G, Kappos L, Olsson TP, Truffinet P, Wang L, Miller A, Freedman MS. Magnetic resonance imaging outcomes from a phase III trial of teriflunomide. Mult Scler. 2013;19(10):1310-9. https://doi.org/10.1177/13524 58513475723.

132. Sprenger T, Kappos L, Radue E-W, Gaetano L, Mueller-Lenke N, Wuerfel J, Thangavelu K, Panzara M, Cavalier S, Wolinsky J. Teriflunomide significantly slows brain volume loss in MS patients irrespective of disability progression (P3.047). Neurology 2016;86 (16 Supplement). https://n. neurology.org/content/86/16_Supplement/P3.047.

133. Freedman MS, T Sprenger T, Radue E-W, Wuerfel J, Miller AE, Thangavelu K, Panzara MA, Cavalier S, Kappos L. Teriflunomide is effective in reducing brain volume loss in previously treated patients: a subgroup analysis of TEMSO SIENA data (P734). ECTRIMS 2016; 2016. https ://onlinelibrary.ectrims-congress.eu/ectrims/2016/32nd/146574/ mark.s.freedman.teriflunomide.is.effective.in.reducing.brain.volume.loss. in.html?f=p6m3e1031014010.

134. Radue E-W, Sprenger T, Gaetano L, Mueller-Lenke N, Wuerfel J, Thangavelu K, Cavalier S, Kappos L. Teriflunomide slows brain volume loss in relapsing MS: A SIENA analysis of the TEMSO MRI dataset (P3.089). Neurology 2016;86 (16 Supplement). https://n.neurology.org/conte nt/86/16_Supplement/P3.089.

135. Wuerfel J, Kappos L, Radue E-W, Gaetano L, Mueller-Lenke N, Thangavelu K, Panzara M, Cavalier S, Wolinsky J, Sprenger T. Teriflunomide slows brain volume loss: subgroup analysis of the SIENA TEMSO MRI dataset (P3.052). Neurology 2016;86 (16 Supplement). https://n.neurology.org/ content/86/16_Supplement/P3.052.

136. Arnold DL, Gold R, Kappos L, Bar-Or A, Giovannoni G, Selmaj K, Yang M, Zhang R, Stephan M, Sheikh SI, Dawson KT. Effects of delayedrelease dimethyl fumarate on MRI measures in the Phase 3 DEFINE study. J Neurol. 2014;261 (9):1794-802. https://doi.org/10.1007/s0041 5-014-7412-x

137. Miller DH, Fox RJ, Phillips JT, Hutchinson M, Havrdova E, Kita M, WheelerKingshott CAM, Tozer DJ, MacManus DG, Yousry TA, Goodsell M, Yang M, Zhang R, Viglietta V, Dawson KT, For the Csi. Effects of delayed-release dimethyl fumarate on MRI measures in the phase 3 CONFIRM study. Neurology. 2015;84(11):1145-52. https://doi.org/10.1212/WNL.00000 00000001360

138. Dupuy SL, Tauhid S, Hurwitz S, Chu R, Yousuf F, Bakshi R. The effect of dimethyl fumarate on cerebral gray matter atrophy in multiple sclerosis. Neurol Ther. 2016. https://doi.org/10.1007/s40120-016-0054-4.

139. Miller DH, Soon D, Fernando KT, MacManus DG, Barker GJ, Yousry TA, Fisher E, O'Connor PW, Phillips JT, Polman CH, Kappos L, Hutchinson M, Havrdova E, Lublin FD, Giovannoni G, Wajgt A, Rudick R, Lynn F, Panzara MA, Sandrock AW. MRI outcomes in a placebo-controlled trial of natalizumab in relapsing MS. Neurology. 2007;68(17):1390-401. https://doi. org/10.1212/01.wnl.0000260064.77700.fd.

140. Radue EW, Stuart WH, Calabresi PA, Confavreux C, Galetta SL, Rudick RA, Lublin FD, Weinstock-Guttman B, Wynn DR, Fisher E, Papadopoulou A, Lynn F, Panzara MA, Sandrock AW. Natalizumab plus interferon beta-1a reduces lesion formation in relapsing multiple sclerosis. J Neurol Sci. 2010;292(1-2):28-35. https://doi.org/10.1016/j.jns.2010.02.012.

141. Portaccio E, Stromillo ML, Goretti B, Hakiki B, Giorgio A, Rossi F, De Leucio A, De Stefano N, Amato MP. Natalizumab may reduce cognitive changes and brain atrophy rate in relapsing-remitting multiple sclerosis - a prospective, non-randomized pilot study. Eur J Neurol. 2013;20(6):986-90. https://doi.org/10.1111/j.1468-1331.2012.03882.x.

142. Vidal-Jordana A, Sastre-Garriga J, Perez-Miralles F, Tur C, Tintore M, Horga A, Auger C, Rio J, Nos C, Edo MC, Arevalo MJ, Castillo J, Rovira A, Montalban X. Early brain pseudoatrophy while on natalizumab therapy is due to white matter volume changes. Mult Scler. 2013;19(9):1175-81. https://doi.org/10.1177/1352458512473190.

143. Rinaldi F, Calabrese M, Seppi D, Puthenparampil M, Perini P, Gallo P. Natalizumab strongly suppresses cortical pathology in 
relapsing-remitting multiple sclerosis. Mult Scler. 2012;18(12):1760-7. https://doi.org/10.1177/1352458512447704.

144. Kapoor R, Ho P-R, Campbell N, Chang I, Deykin A, Forrestal F, Lucas N, Yu B, Arnold DL, Freedman MS. Effect of natalizumab on disease progression in secondary progressive multiple sclerosis (ASCEND): a phase 3, randomised, double-blind, placebo-controlled trial with an open-label extension. Lancet Neurol. 2018;17(5):405-15.

145. Arpin EC, Sobrino TG, Vivero CD, del Campo Amigo Jorrin M, Regal AR, Gonzalez JP, Bouzas ML. Changes in brain atrophy indices in patients with relapsing-remitting multiple sclerosis treated with natalizumab. Neurodegener Dis Manag. 2016;6(1):5-12. https://doi.org/10.2217/ nmt.15.53.

146. Investigators TCT. Alemtuzumab vs interferon beta-1a in early multiple sclerosis. N Engl J Med. 2008;359(17):1786-801. https://doi.org/10.1056/ nejmoa0802670.

147. Cohen JA, Coles AJ, Arnold DL, Confavreux C, Fox EJ, Hartung HP, Havrdova E, Selmaj KW, Weiner HL, Fisher E, Brinar W, Giovannoni G, Stojanovic M, Ertik BI, Lake SL, Margolin DH, Panzara MA, Compston DA. Alemtuzumab versus interferon beta $1 \mathrm{a}$ as first-line treatment for patients with relapsing-remitting multiple sclerosis: a randomised controlled phase 3 trial. Lancet. 2012;380(9856):1819-28. https://doi. org/10.1016/s0140-6736(12)61769-3.

148. Coles AJ, Twyman CL, Arnold DL, Cohen JA, Confavreux C, Fox EJ, Hartung HP, Havrdova E, Selmaj KW, Weiner HL, Miller T, Fisher E, Sandbrink R, Lake SL, Margolin DH, Oyuela P, Panzara MA, Compston DA. Alemtuzumab for patients with relapsing multiple sclerosis after disease-modifying therapy: a randomised controlled phase 3 trial. Lancet. 2012;380(9856):1829-39. https://doi.org/10.1016/s0140-6736(12)61768-1.

149. Traboulsee A, Barnett M, Comi G, LaGanke C, Pelletier D, Rovira A, Schippling S, Margolin DH, Thangavelu K, Nakamura K, Arnold DL, Investigators obotC-MlaC-MI. Alemtuzumab durably slows brain volume loss over 6 years in the absence of continuous treatment in patients with active RRMS who were treatment-naive (CARE-MS I) or had an inadequate response to prior therapy (CARE-MS II) (P1181). ECTRIMS 2016; 2016.

150. Coles AJ, Cohen JA, Fox EJ, Giovannoni G, Hartung HP, Havrdova E, Schippling S, Selmaj KW, Traboulsee A, Compston DAS, Margolin DH, Thangavelu K, Chirieac MC, Jody D, Xenopoulos P, Hogan RJ, Panzara MA, Arnold DL. Alemtuzumab CARE-MS II 5-year follow-up: efficacy and safety findings. Neurology. 2017;89(11):1117-26. https://doi. org/10.1212/wnl.0000000000004354.

151. Arnold DL, Kappos L, Khan O, Gauthier SA, Greenberg S, Ma W, Wang P, Elkins J, Sabatella G. Reduction in brain volume loss in patients receiving daclizumab HYP versus intramuscular interferon beta-1a: results of the DECIDE study (P558). ECTRIMS 2015; 2015.

152. Borges IT, Shea CD, Ohayon J, Jones BC, Stone RD, Ostuni J, Shiee N, McFarland H, Bielekova B, Reich DS. The effect of daclizumab on brain atrophy in relapsing-remitting multiple sclerosis. Mult Scler Relat Disord. 2013;2(2):133-40. https://doi.org/10.1016/j.msard.2012.10.002.

153. Gold R, Giovannoni G, Selmaj K, Havrdova E, Montalban X, Radue EW, Stefoski D, Robinson R, Riester K, Rana J, Elkins J, O’Neill G. Daclizumab high-yield process in relapsing-remitting multiple sclerosis (SELECT): a randomised, double-blind, placebo-controlled trial. Lancet. 2013;381 (9884):2167-75. https://doi.org/10.1016/s0140-6736(12)62190-4.

154. Arnold D, Bar-Or A, Comi G, Hartung H-P, Hauser S, Kappos L, Lublin F, Selmaj K, Traboulsee A, Klingelschmitt G, Masterman D, Fontoura P, Chin $\mathrm{P}$, Garren $\mathrm{H}$, Wolinsky J. Effect of ocrelizumab on MRI inflammatory and neurodegenerative markers of disease in patients with relapsing multiple sclerosis: analysis of the phase III, double-blind, double-dummy, interferon beta-1a-controlled OPERA I and OPERA II studies (S49.002). Neurology 2016;86 (16 Supplement). https://n.neurology.org/conte nt/86/16_Supplement/S49.002.

155. Montalban X, Hemmer B, Rammohan K, Giovannoni G, De Seze J, Bar-Or A, Arnold D, Sauter A, Masterman D, Fontoura P, Garren H, Chin P, Wolinsky J. Efficacy and safety of ocrelizumab in primary progressive multiple sclerosis: results of the phase III double-blind, placebo-controlled ORATORIO study (\$49.001). Neurology 2016;86 (16 Supplement). https://onlinelibrary.ectrims-congress.eu/ectrims/2015/31st/116701/ xavier.montalban.efficacy.and.safety.of.ocrelizumab.in.primary.progr essive.html?f=m3.
156. Bruck W, Pfortner R, Pham T, Zhang J, Hayardeny L, Piryatinsky V, Hanisch UK, Regen T, van Rossum D, Brakelmann L, Hagemeier K, Kuhlmann T, Stadelmann C, John GR, Kramann N, Wegner C. Reduced astrocytic NF-kappaB activation by laquinimod protects from cuprizone-induced demyelination. Acta Neuropathol. 2012;124(3):411-24. https://doi. org/10.1007/s00401-012-1009-1.

157. Comi G, Jeffery D, Kappos L, Montalban X, Boyko A, Rocca MA, Filippi M. Placebo-Controlled Trial of Oral Laquinimod for Multiple Sclerosis. N Engl J Med. 2012;366(11):1000-9. https://doi.org/10.1056/NEJMoa1104 318.

158. Vollmer TL, Sorensen PS, Selmaj K, Zipp F, Havrdova E, Cohen JA, Sasson N, Gilgun-Sherki Y, Arnold DL. A randomized placebo-controlled phase III trial of oral laquinimod for multiple sclerosis. J Neurol. 2014;261(4):773-83. https://doi.org/10.1007/s00415-014-7264-4.

159. Alroughani R, Deleu D, El Salem K, Al-Hashel J, Alexander KJ, Abdelrazek MA, Aljishi A, Alkhaboori J, Al Azri F, Al Zadjali N. A regional consensus recommendation on brain atrophy as an outcome measure in multiple sclerosis. BMC Neurol. 2016;16(1):240.

160. Filippi M, Rovaris M, lannucci G, Mennea S, Sormani MP, Comi G. Whole brain volume changes in patients with progressive MS treated with cladribine. Neurology. 2000;55(11):1714-8.

161. Giovannoni G, Comi G, Cook S, Rammohan K, Rieckmann P, Sørensen PS, Vermersch P, Chang P, Hamlett A, Musch B, Greenberg SJ. A placebocontrolled trial of oral cladribine for relapsing multiple sclerosis. N Engl J Med. 2010;362(5):416-26. https://doi.org/10.1056/NEJMoa0902533.

162. De Stefano N, Giorgio A, Battaglini M, De Leucio A, Hicking C, Dangond F, Giovannoni G, Sormani MP. Reduced brain atrophy rates are associated with lower risk of disability progression in patients with relapsing multiple sclerosis treated with cladribine tablets. Mult Scler. 2018;24(2):222-6. https://doi.org/10.1177/1352458517690269.

163. De Stefano N, Giorgio A, et al. Response to 'Does cladribine have an impact on brain atrophy in people with relapsing remitting multiple sclerosis?' by Schiffmann et al. Mult Scler. 2018;24(10):1388-9. https:// doi.org/10.1177/1352458517748476.

164. Schiffmann I, Scheiderbauer J, Riemann-Lorenz K, Heesen C. Does cladribine have an impact on brain atrophy in people with relapsing remitting multiple sclerosis? Mult Scler. 2018;24(10):1387-8. https://doi. org/10.1177/1352458517749895.

165. Dardiotis E, Arseniou S, Sokratous M, Tsouris Z, Siokas V, Mentis AA, Michalopoulou A, Andravizou A, Dastamani M, Paterakis K, Bogdanos D, Brotis A. Vitamin B12, folate, and homocysteine levels and multiple sclerosis: a meta-analysis. Mult Scler Relat Disord. 2017;17:190-7. https ://doi.org/10.1016/j.msard.2017.08.004.

166. Dardiotis E, Nousia A, Siokas V, Tsouris Z, Andravizou A, Mentis AA, Florou D, Messinis L, Nasios G. Efficacy of computer-based cognitive training in neuropsychological performance of patients with multiple sclerosis: a systematic review and meta-analysis. Mult Scler Relat Disord. 2018;20:58-66. https://doi.org/10.1016/j.msard.2017.12.017.

167. Sokratous M, Dardiotis E, Bellou E, Tsouris Z, Michalopoulou A, Dardioti M, Siokas V, Rikos D, Tsatsakis A, Kovatsi L, Bogdanos DP, Hadjigeorgiou GM. CpG island methylation patterns in relapsing-remitting multiple sclerosis. J Mol Neurosci. 2018;64(3):478-84. https://doi.org/10.1007/ s12031-018-1046-x.

168. Dardiotis E, Tsouris Z, Aslanidou P, Aloizou AM, Sokratous M, Provatas A, Siokas V, Deretzi G, Hadjigeorgiou GM. Body mass index in patients with multiple sclerosis: a meta-analysis. Neurol Res. 2019. https://doi. org/10.1080/01616412.2019.1622873.

169. Sokratous M, Dardiotis E, Tsouris Z, Bellou E, Michalopoulou A, Siokas V, Arseniou S, Stamati T, Tsivgoulis G, Bogdanos D, Hadjigeorgiou GM. Deciphering the role of DNA methylation in multiple sclerosis: emerging issues. Auto Immun Highlights. 2016;7(1):12. https://doi. org/10.1007/s13317-016-0084-z.

170. Efthymiou G, Dardiotis E, Liaskos C, Marou E, Tsimourtou V, Rigopoulou El, Scheper T, Daponte A, Meyer W, Sakkas LI, Hadjigeorgiou G, Bogdanos DP. Immune responses against Helicobacter pylori-specific antigens differentiate relapsing remitting from secondary progressive multiple sclerosis. Sci Rep. 2017;7(1):7929. https://doi.org/10.1038/ s41598-017-07801-9.

171. Dardiotis E, Panayiotou E, Siokas V, Aloizou A-M, Christodoulou K, Hadjisavvas A, Pantzaris M, Grigoriadis N, Hadjigeorgiou GM, Kyriakides T. Gene variants of adhesion molecules predispose to MS: a case-control 
study. Neurol Genet. 2019;5(1):e304. https://doi.org/10.1212/nxg.00000 00000000304

172. Dardiotis E, Panayiotou E, Provatas A, Christodoulou K, Hadjisavvas A, Antoniades A, Lourbopoulos A, Pantzaris M, Grigoriadis N, Hadjigeorgiou GM, Kyriakides T. Gene variants of adhesion molecules act as modifiers of disease severity in MS. Neurol Neuroimmunol Neuroinflamm. 2017:4(4):e350. https://doi.org/10.1212/nxi.00000000000000350.

173. De Stefano N, Sormani MP, Stubinski B, Blevins G, Drulovic JS, Issard D, Shotekov P, Gasperini C. Efficacy and safety of subcutaneous interferon beta-1a in relapsing-remitting multiple sclerosis: further outcomes from the IMPROVE study. J Neurol Sci. 2012;312(1-2):97-101. https://doi. org/10.1016/j.jns.2011.08.013.

174. Hardmeier M, Wagenpfeil S, Freitag P, Fisher E, Rudick RA, Kooijmans M, Clanet M, Radue EW, Kappos L. Rate of brain atrophy in relapsing MS decreases during treatment with IFNbeta-1a. Neurology. 2005;64(2):236-40. https://doi.org/10.1212/01.wnl.0000149516.30155 .b8.

175. Molyneux PD, Kappos L, Polman C, Pozzilli C, Barkhof F, Filippi M, Yousry T, Hahn D, Wagner K, Ghazi M, Beckmann K, Dahlke F, Losseff N, Barker GJ, Thompson AJ, Miller DH. The effect of interferon beta-1b treatment on MRI measures of cerebral atrophy in secondary progressive multiple sclerosis. European Study Group on Interferon beta-1b in secondary progressive multiple sclerosis. Brain. 2000;123(Pt 11):2256-63.

176. Kappos L, Freedman MS, Polman CH, Edan G, Hartung HP, Miller DH, Montalban X, Barkhof F, Radu EW, Bauer L, Dahms S, Lanius V, Pohl C, Sandbrink R. Effect of early versus delayed interferon beta- $1 \mathrm{~b}$ treatment on disability after a first clinical event suggestive of multiple sclerosis: a 3-year follow-up analysis of the BENEFIT study. Lancet. 2007;370(9585):389-97. https://doi.org/10.1016/s0140-6736(07)61194 -5 .

177. Kappos L, Freedman MS, Polman CH, Edan G, Hartung HP, Miller DH, Montalban X, Barkhof F, Radu EW, Metzig C, Bauer L, Lanius V, Sandbrink
R, Pohl C. Long-term effect of early treatment with interferon beta- $1 \mathrm{~b}$ after a first clinical event suggestive of multiple sclerosis: 5-year active treatment extension of the phase 3 BENEFIT trial. Lancet Neurol. 2009;8(11):987-97. https://doi.org/10.1016/s1474-4422(09)70237-6.

178. Khan O, Rieckmann P, Boyko A, Selmaj K, Zivadinov R. Three times weekly glatiramer acetate in relapsing-remitting multiple sclerosis. Ann Neurol. 2013;73(6):705-13. https://doi.org/10.1002/ana.23938.

179. Lublin FD, Cofield SS, Cutter GR, Conwit R, Narayana PA, Nelson F, Salter AR, Gustafson T, Wolinsky JS. Randomized study combining interferon and glatiramer acetate in multiple sclerosis. Ann Neurol. 2013;73(3):327-40. https://doi.org/10.1002/ana.23863.

180. O'Connor P, Filippi M, Arnason B, Comi G, Cook S, Goodin D, Hartung HP, Jeffery D, Kappos L, Boateng F, Filippov V, Groth M, Knappertz V, Kraus C, Sandbrink R, Pohl C, Bogumil T, O'Connor P, Filippi M, Arnason B, Cook S, Goodin D, Hartung HP, Kappos L, Jeffery D, Comi G. 250 microg or 500 microg interferon beta-1 $\mathrm{b}$ versus $20 \mathrm{mg}$ glatiramer acetate in relapsingremitting multiple sclerosis: a prospective, randomised, multicentre study. Lancet Neurol. 2009;8(10):889-97. https://doi.org/10.1016/s1474 $-4422(09) 70226-1$

181. Kappos L, Fox R, Gold R, Arnold D, Potts J, Zhang A, Kurukulasuriya N. Sustained low rate of brain volume loss under long-term delayedrelease dimethyl fumarate treatment in relapsing-remitting multiple sclerosis patients: results from the ENDORSE study (P7.243). Neurology 2015;84 (14 Supplement). https://n.neurology.org/content/84/14_ Supplement/P7.243.

\section{Publisher's Note}

Springer Nature remains neutral with regard to jurisdictional claims in published maps and institutional affiliations.
Ready to submit your research? Choose BMC and benefit from:

- fast, convenient online submission

- thorough peer review by experienced researchers in your field

- rapid publication on acceptance

- support for research data, including large and complex data types

- gold Open Access which fosters wider collaboration and increased citations

- maximum visibility for your research: over $100 \mathrm{M}$ website views per year

At BMC, research is always in progress.

Learn more biomedcentral.com/submissions 